\title{
Influence of oil exposure on the physiology and ecology of the common sole Solea solea: Experimental and field approaches
}

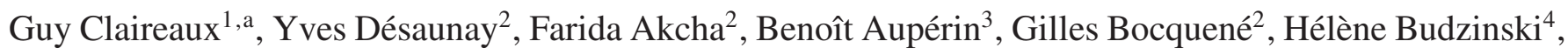
Jean-Pierre Cravedii ${ }^{5}$, Fariba Davoodi ${ }^{1}$, Robert Galois ${ }^{1}$, Camille Gilliers ${ }^{2}$, Christelle Goanvec ${ }^{6}$, Daniel Guérault ${ }^{2}$, Nathalie Imbert ${ }^{7}$, Olivier Mazéas ${ }^{4}$, Guy Nonnotte ${ }^{6}$, Liliane Nonnotte ${ }^{6}$, Patrick Prunet ${ }^{3}$, Philippe Sébert ${ }^{8}$ and Aurélie Vettier ${ }^{8}$

Centre de Recherche sur les Écosystèmes marins et aquacoles (CNRS-IFREMER), 17137 L'Houmeau, France

2 IFREMER, Laboratoire d'Écologie halieutique, rue de l'Ile d'Yeu, 44311 Nantes Cedex 03, France

3 INRA, Station commune de recherches en ichtyophysiologie, Biodiversité et Environnement, Équipe physiologie de l'adaptation et du stress, Campus de Beaulieu, 35042 Rennes Cedex, France

${ }^{4}$ Laboratoire de physico-toxicochimie des systèmes naturels, Université de Bordeaux, 351 cours de la Libération, 33405 Talence Cedex, France

5 INRA, Laboratoire des xénobiotiques, UMR 1089, Toulouse, France

${ }^{6}$ Laboratoire de biologie et de physiologie cellulaire, Université de Bretagne Occidentale, UFR Sciences et Techniques, 6 avenue Le Gorgeu, BP 809, 29285 Brest Cedex, France

${ }^{7}$ Université de La Rochelle, Laboratoire de biologie et environnement marins, avenue M. Crépeau, La Rochelle, 17042 Cedex 1, France

8 Université de Bretagne Occidentale, Laboratoire de physiologie, Unité haute pression et métabolisme EA 3879, UFR Médecine, CS 93837, Brest 29238 Cedex 03, France

Received 11 February 2004; Accepted 2 September 2004

\begin{abstract}
Evaluating the ecological impact of an oil spill is a complex issue requiring coherently articulated examination of the sequence of interactions that link the cell, where contaminants exert their effects, to the ecosystem, where interactions with human activities arise. This sequence of interactions traverses the frontiers between scientific disciplines (chemistry, toxicology, physiology, and fisheries ecology). Using the common sole (Solea solea L.) as a model species for the coastal habitats polluted by the "Erika" oil spill, our research project attempted to define indices of functional integrity that characterised the consequences of fuel exposure at the different biological levels. The coupling of field observations with experimental laboratory work revealed how functional alterations which are readily observable within individuals and their organs are progressively obscured as investigation progresses towards more complex organisational levels. Some of the approaches and indices are proposed as instruments for evaluating the impact of contamination by hydrocarbons.
\end{abstract}

Key words: Oil spill / Complex system approach / Common sole / Physiological ecology

Résumé - Influence de l'exposition au fioul sur la physiologie et l'écologie de la sole commune Solea solea : approches expérimentales et in situ. L'évaluation des conséquences écologiques d'une marée noire est un problème complexe qui requiert un examen articulé et cohérent de la chaîne d'interactions qui relie l'échelle cellulaire, à laquelle agit le contaminant, à l'échelle écosystémique, où se situent les interactions avec les activités humaines. Cette chaîne d'interactions traverse les frontières des disciplines scientifiques (chimie, toxicologie, physiologie, écologie halieutique). En prenant la sole (Solea solea L.) comme espèce cible - espèce caractéristique des habitats côtiers pollués par l'«Erika»- le programme de recherche ECTOPHY est une première tentative de mise en place d'une approche multidisciplinaire visant à définir, valider et mettre en relation des indicateurs d'intégrité fonctionnelle caractérisant les différents niveaux biologiques. Le couplage d'observations in situ avec des expositions en milieu contrôlé a montré que des pertes de fonctionnalité évidentes et durables à l'échelle de l'individu sont masquées à l'échelle de la population. Certaines des approches (in situ ou expérimentale) et certains des indicateurs testés peuvent être proposés comme instruments utilisables dans le cadre d'évaluation d'impact de pollutions par des hydrocarbures.

\footnotetext{
${ }^{a}$ Corresponding author: guy.claireaux@ifremer.fr
} 


\section{Introduction}

Following the 1999 Erika oil spill, bays and estuaries of the Northern Bay of Biscay were exposed to petroleum (Foreword, this issue). A total of 20000 tons of fuel drifted for several weeks in the open sea and spread along $400 \mathrm{~km}$ of coastline, from western Brittany to the northern tips of the islands of Ré and Oléron. These coastal habitats comprise important nurseries for juveniles of numerous fish species, in particular the common sole (Koutsikopoulos et al. 1989). Adult sole spawn during the first three months of the year (with a peak in early March in North Biscay), then pelagic eggs and larvae transform into juvenile benthic fish that concentrate in shallow waters and estuaries in June and July. Juveniles remain in coastal waters for 2 to 3 years until they reach maturity and migrate to deeper waters. From a fisheries point of view, the common sole is a major resource, 1795 tons of sole are harvested yearly in the Bay of Biscay, with a value of 17.7 M€ (Léauté and CaillMilly 2003). However, since 1993 the spawning biomass of the Bay of Biscay stock has undergone a constant decline and it is currently at risk, with the lowest level of recruitment of the last 20 years recorded for the year class 1999 (Anonymous 2003).

Considering the potential biological and economic consequences of the contamination of coastal nursery areas, we launched a research program that combined experimental and field approaches to investigate how the Erika oil spill might have affected the physiological and ecological performance of juvenile sole.

The term "performance" has been used extensively in the literature but, surprisingly, little attention has been given to the interpretation of fish performance at the various levels of biological organisation (Whitfield and Elliott 2002). At a cellular level, performance describes structural integrity and maintenance of biochemical processes. Individual performance relates to the morphological and functional integrity of the whole animal. Population performance describes the sustainability and maintenance of a particular population. At the community and ecosystem levels, performance is described by the assemblage of organisms and by the relationships between species in that assemblage. Evaluating the ecological implications of a particular environmental event requires that all of these levels of biological organisation, and their interactions, be identified and considered (Fig. 1). For instance, the cell is the level where the interactions between a fish and its physico-chemical environment occur, whereas the ecosystem is the level where the interactions with human activities take place. Because environmental impacts propagate across organisational levels, it is essential that any change in performance at one level be properly linked to mechanisms and processes taking place at the level immediately below. It is also important that the relevance of a change at a given level of integration be examined at the organisational level immediately above.

At each level of integration, the changes in performance observed as the result of an environmental event (i.e., "signal") are measured against a background of variability (i.e., "noise"). This noise has two main sources. At the cellular and individual levels it mainly originates from the inherent inter-individual variability in response traits. At higher organisational levels, this background noise largely results from

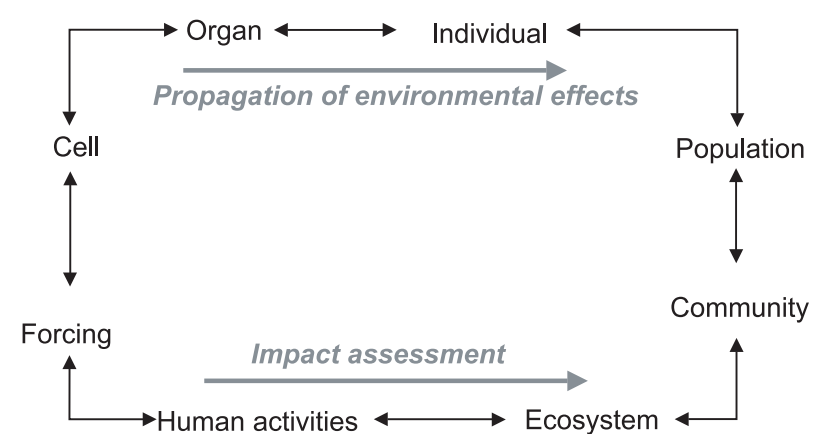

Fig. 1. The cycle of interactions between biological levels.

rapidly increasing numbers of factors that influence a particular performance, each generating a specific pattern of variability. Recruitment in fish stocks is a classical example of an integrated performance with a correspondingly high level of inter-annual variability. In sole, for instance, inter-annual variability in recruitment at the Bay of Vilaine nursery scale is in the range 1 to 10 (Le Pape et al. 2003b), whereas it varies only by a factor 2.5 at the Bay of Biscay stock scale (Anonymous 2003). Following the accident of the "Exxon Valdez" in Alaska, Hilborn (1996) conducted a critical analysis of the methods used to evaluate the ecological consequences of oil spills in marine habitats. This analysis underlined the need for states of reference that provided reliable information about natural environmental variability and its potential influence upon the biology of fishes. Carefully conducted and integrated experimental work was recognised as an essential element for disentangling anthropogenic and natural influences (Hilborn 1996). More recently, Peterson et al. (2003) emphasised the need to consider long term consequences of sublethal exposure to pollution and their cascading effects in physically confined systems such as spawning areas and nurseries.

In order to investigate the long-term consequences of exposure of marine nurseries to petroleum, our research project combined three aspects. The first was essentially experimental and aimed at examining, under laboratory conditions, the consequences of oil exposure on the physiological mechanisms involved in environmental adaptation. The second aspect validated the relevance of the laboratory phase by attempting a transition to field conditions using tidal earthen ponds as mesocosms. The last aspect involved fieldwork and research vessel cruises and aimed at authenticating the contamination in natura and at testing the ecological relevance of the experimental stages of our project.

\section{Materials and methods}

\subsection{Contamination protocol}

At the time when these experiments were conducted, fuel from the tanker Erika was no longer available and so fuel No. 2 was used as an alternative. The polycyclic aromatic hydrocarbon (PAH) composition of these two fuels was comparable when assessed as described by Mazéas and Budzinski (2001), although differences were noticed particularly with regard to 


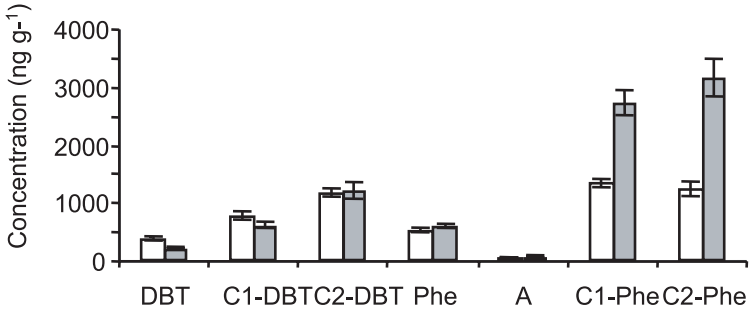

PAH (light)

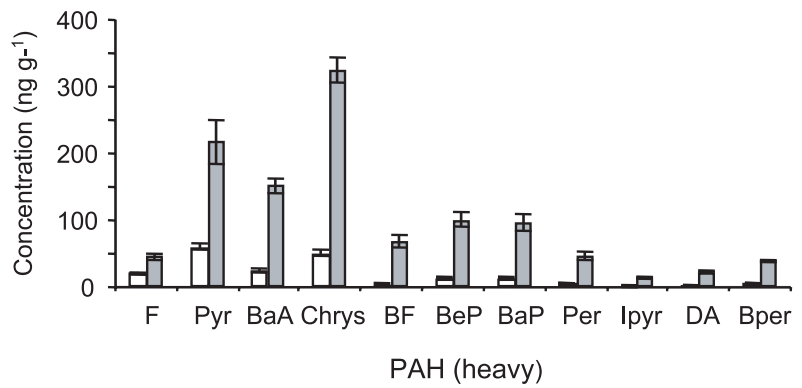

Fig. 2. PAH composition of fuel \#2 (white boxes) compared with that of the fuel recovered from Erika (grey boxes).

long-chain PAH (Fig. 2). This fuel No. 2 is therefore expected to be less toxic to fish than the true Erika fuel.

The Erika event was characterised by drifting slicks and weakly contaminated sediments (Tronczynski et al. 2004). In order mimic these contamination conditions, fish were exposed with fuel that was simply poured onto the surface of the experimental tanks. A gentle air bubbling allowed the aeration of the water and the homogeneity of the soluble phase. We considered that this exposure regime represented an acceptable compromise between realistic contamination conditions and the need to regulate other environmental parameters within reasonable limits. A static exposure protocol was employed because it was not feasible to manage decontamination of the large volumes of water waste that would have been generated by a flow through system $\left(50-200 \mathrm{~L} \mathrm{~h}^{-1}\right)$. In order to maintain the physico-chemical quality of the water (particularly with regard to $\mathrm{pH}$ and ammonia), fish could not be kept in the exposure water for more than a few days. Thus, to compensate for the limitations of the exposure period, relatively high doses of fuel were employed.

\subsection{Laboratory experimental phase}

Sole (1-group and 2-group; length 15-22 cm) were obtained by trawling at field site 4 (Pertuis Breton, Fig. 3). Upon arrival at the laboratory they were transferred to indoor rearing tanks $(2 \times 2 \mathrm{~m})$ and submitted to a sanitary antibiotic treatment during 7 days. An additional 4-week acclimation period was allowed during which fish were fed with fresh mussel and oyster flesh. Animals were then randomly attributed to experimental groups of 40 individuals and placed in $500 \mathrm{~L}$ rearing tanks covered with a polyethylene lining. The bottom of those tanks was topped with $1 \mathrm{~cm}$ of sand.

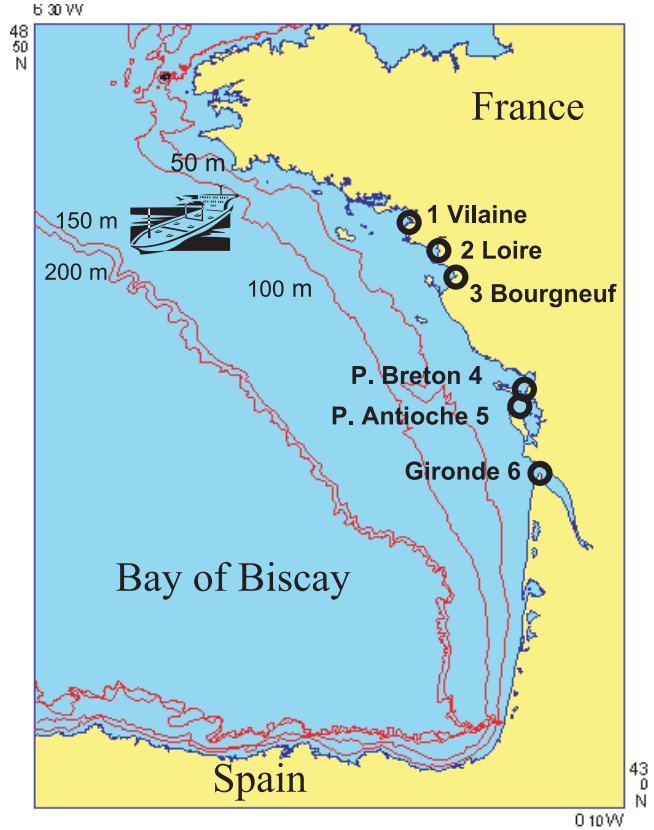

Fig. 3. Location of the Erika wreckage and surveyed coastal sites. 1: Vilaine Estuary; 2: Loire Estuary; 3: Bourgneuf Bay; 4: Pertuis Breton; 5: Pertuis d'Antioche; 6: Gironde Estuary.

The fuel exposure conditions tested are summarised in Table 1. Fuel to water ratios $(1 / 100,1 / 200,1 / 1000$ or $1 / 2000$ $\mathrm{vol} / \mathrm{vol})$ were obtained by directly adding fuel onto the surface of the experimental tanks. There was no direct contact between the fish in the sand and the fuel floating at the surface. Typically fuel exposure lasted 5 days. During that period the water was not renewed and animals were not fed. Following fuel-exposure, fish were transferred into unpolluted tanks where they were left undisturbed for about 2 hours. Each fish was then anaesthetised $\left(0.2 \mathrm{ml} \mathrm{L}^{-1}\right.$ of 2-phenoxyethanol) and its length and weight measured. Blood was sampled via the caudal vein and the fish was killed by a sharp blow in the cervical region before the various tissues (gills, bile, liver, white muscle) were dissected. The whole procedure was completed within $8 \mathrm{~h}$.

\section{Toxicology}

Liver ethoxyresorufin-O-deethylase (EROD) activity was selected as a biomarker of exposure to PAH (Burgeot et al. 1994; Kirby et al. 1999). It was measured as described by Galgani and Payne (1991) from microsomes prepared from homogenised liver according to Monod et al. (1994).

Total PAH in white muscle and liver were measured following the methods described in Budzinski et al. (2004). For the determination of $\mathrm{PAH}$ in the aqueous phase, water was first collected in clean glass bottles and then passed through a $0.7 \mu \mathrm{m} \mathrm{GF} / \mathrm{F}$ filter (VWR, Strasbourg, France) to separate dissolved $\mathrm{PAH}$ from $\mathrm{PAH}$ adsorbed on particulate matter. Dissolved PAH were then immediately extracted by passing water sample $(1 \mathrm{~L})$ through an octadecyl speedisk on which $\mathrm{PAH}$ are retained. Analytes were recovered by successive elutions with dichloromethane and dichloromethane/ethyle 
Table 1. Fuel to water ratios and PAH concentrations in water (1 analysis on $1 \mathrm{~L}$ of the dissolved phase). The summed PAH are the following: phenanthrene, fluoranthene, pyrene, benz(a)anthracene, chrysene+triphenylene, benzo(b)fluoranthene, benzo(j)fluoranthene benzo(k)fluoranthene, benzo(a)pyrene, dibenz(a,h)anthracene + dibenz(a,c)anthracene, benzo(g,h,i)perylene, indeno(1,2,3-cd)pyrene.

$\left.\begin{array}{ccccccc}\hline & \begin{array}{c}\text { Temperature } \\ \left({ }^{\circ} \mathrm{C}\right)\end{array} & \text { Control } & \begin{array}{c}1 / 2000 \\ (\mathrm{vol} / \mathrm{vol})\end{array} & \begin{array}{c}1 / 1000 \\ (\mathrm{vol} / \mathrm{vol})\end{array} & \begin{array}{c}1 / 200 \\ (\mathrm{vol} / \mathrm{vol})\end{array} & - \\ (\mathrm{vol} / \mathrm{vol})\end{array}\right)$

acetate $(1 / 1 ; \mathrm{v} / \mathrm{v})$. Extracts were then purified on alumina $\left(\mathrm{Al}_{2} \mathrm{O}_{3}\right)$ and silica $\left(\mathrm{SiO}_{2}\right)$ columns and analysed by GC/MS using single ion monitoring mode (Budzinski et al. 1999). $\mathrm{PAH}$ were quantified by internal standard quantification using perdeutarated PAH (Baumard and Budzinski 1997).

\section{Biochemistry of cellular bioenergetics}

Two parallel approaches were followed. In a global approach, the energetics of the white muscle was examined through the determination of ATP, ADP, AMP and IMP concentration and the calculation of the cellular energy charge (EC) and compensated energy charge (EC'). These measurements were performed using specific HPLC protocols (Cann-Moisan et al. 1989; Vettier and Sébert 2004). In a more specific approach, activity of white muscle cytochrome C oxydase (COX) was determined (Vettier and Sébert 2004). $\mathrm{COX}$ is the last enzyme complex of the mitochondrial respiratory chain and since it controls the oxidative phosphorylation process it represents a valid indicator of cellular energetics. COX activity was determined in the heart (ventricle) and white muscle.

\section{Gill histology and gill Na,K-ATPase activity}

Gill samples were put in fixative (Bouin) for at least $24 \mathrm{~h}$ and were then dehydrated via alcohol bathing (Martoja and Martoja-Pierson 1967). Samples were then embedded in paraplast, sliced $(5 \mu \mathrm{m})$ and stained with a mixture of hematoxylineosin or periodic acid schiff (PAS) according to routine procedures (Martoja and Martoja-Pierson 1967; Vethaak and Wester 1996; Stehr et al. 2003).

Gill Na,K-ATPase plays a major role in osmoregulation and the preservation of the osmotic and ionic characteristics of the extracellular compartment. In vitro $\mathrm{Na}, \mathrm{K}$-ATPase activity was assessed via routine biochemical assays. In this case, gill tissue samples were freeze clamped immediately upon dissection and then kept at $-80^{\circ} \mathrm{C}$ until analysis.

\section{Isometric tension measurements using ventricular muscle strips}

The preparation of cardiac tissues for measuring isometric tension has been described elsewhere (Shiels et al. 1998). Briefly, fish (control, $n=10$; fuel-exposed, $n=10$ ) were anaesthetised $\left(0.2 \mathrm{ml} \mathrm{L}^{-1}\right.$ of 2-phenoxyethanol) and killed by cervical dislocation. The heart was quickly excised and placed in a dish of ice-chilled, oxygenated physiological saline. The ventricle was isolated and cut length-wise to expose the lumen. Two $1 \mathrm{~mm}$-wide pieces of muscle were dissected from each heart with the aid of a dissecting microscope. Each muscle strip was hung in a water-jacketed organ bath between an isometric force transducer (Somedic Medical Ltd, Sweden) and a fixed post. The tissue was immersed in oxygenated saline and temperature was controlled $\left(15{ }^{\circ} \mathrm{C}\right)$. Because adrenaline (AD) is present at nanomolar concentrations in the circulation of resting fish, a tonic level of $\mathrm{AD}(1 \mathrm{nM})$ was utilised for the control situation and a AD concentration of $1 \mu \mathrm{M}$ was tested to provide a maximal level of adrenergic stimulation (Reid et al. 1998; Gamperl et al. 1994). For each force-frequency trial, the pacing frequency was increased from $0.2 \mathrm{~Hz}$ to $0.5,0.8,1.0$, $1.2,1.5,1.8$ and $2.0 \mathrm{~Hz}$ (or until the preparation became arrhythmic at frequencies $>2.0 \mathrm{~Hz}$ ). A full description of the protocol followed is given in Mercier et al. (2002).

\section{Aerobic metabolism}

Oxygen consumption rate $\left(\mathrm{MO}_{2}\right.$ in $\left.\mathrm{mgO}_{2} \mathrm{~kg}^{-1} \mathrm{~h}^{-1}\right)$ of fuelexposed fish $(n=8 ; 1 / 200 \mathrm{vol} / \mathrm{vol})$ was compared to that of control fish $(n=8)$. The experimental set up and protocol have been described in detail by Lefrançois and Claireaux (2003). Values of oxygen consumption were standardised to a $100 \mathrm{~g}$ animal using a mass exponent of 0.8 (Van den Thillart et al. 1994).

\subsection{Tidal earthen pond mesocosms}

This part of the project aimed at considering, from an ecological perspective, the loss in functional and morphological integrity and/or performance that might follow the experimental exposure to fuel. Two series of experiments were performed, the first one with large animals (1- and 2-groups; total length $17-25 \mathrm{~cm}$ ) from site 4 (Pertuis Breton, Fig. 3), the second with younger animals (0-group; total length $6-10 \mathrm{~cm}$ ) from site 1 (Vilaine Estuary). In the first case, the fuel to water ratio tested was $1 / 200$ and the duration of the exposure was 5 days at temperature of $16^{\circ} \mathrm{C}$. In the second case, fuel to water ratio and exposure duration were divided by 5 (i.e., 1/1000 and $24 \mathrm{~h}$ respectively) and water temperature during fuel exposure was $19^{\circ} \mathrm{C}$.

The earthen tidal ponds $\left(200 \mathrm{~m}^{2}, 1 \mathrm{~m}\right.$ depth) are situated at the CREMA-L'Houmeau field site (near site 4; Fig. 3). Preliminary experiments and empirical observations have shown 
that the natural fauna present in these tidal ponds provides a carrying capacity corresponding to the nutritional needs of approximately $3 \mathrm{~kg}$ of fish. During the experimental period, water temperature in the ponds fluctuated between 15 and $24{ }^{\circ} \mathrm{C}$ and salinity between 25 and $29 \%$. Water oxygenation was maintained using mechanical aerators.

\section{Experiment 1: Growth rate of juvenile sole $(17-25 \mathrm{~cm})$ exposed to $1 / 200$ fuel for 5 days}

A group of 80 soles captured in May 2002 at site 4 (Fig. 3) was divided in two subgroups. Fish from the first subgroup were weighed, their length was measured and they were tagged subcutaneously with a transponder (pit tag). They were then exposed to fuel $(1 / 200)$ for 5 days following the same procedure as for the laboratory phase. Fish from the second subgroup were submitted to the same manipulation but were not exposed to fuel. Fish from these two groups were then distributed randomly among two tidal earthen ponds. Three months later, both ponds were drained and fish were individually identified, weighed and their length measured. Fish were then returned to their initial pond for another 3-month period at the end of which the same measurements were performed again. The final observation provided the survival rate and the individual growth rate.

\section{Experiment 2: Growth and condition factor of young of the year sole $(6-10 \mathrm{~cm})$ exposed to $1 / 1000$ fuel for 24 hours}

A group of 630 juvenile soles (4 to 5 months old) were obtained from site 1 (Fig. 3) in July 2002 and transferred, by road, to the CREMA -L'Houmeau field site (transportation duration: $3 \mathrm{~h}$ ). Only 15 individuals died during the transfer. Upon arrival, sole were distributed among 2 subgroups of about 300 individuals and placed in $400 \mathrm{~L}$ rearing tanks supplied with running seawater $\left(19^{\circ} \mathrm{C}\right)$. Fish were too small to be tagged. One subgroup was exposed to fuel $(1 / 1000,24 \mathrm{~h})$ and then both control and fuel-exposed subgroups were placed in two identical but distinct tidal ponds (July 8th). Water condition in the ponds was monitored continuously. Sampling took place on September 4th (30 fish perponds) and finally in October 24 th at termination of the trial. Plankton nets $(315 \mu \mathrm{m})$ were placed around the exit pipe during draining of the ponds to sample the mobile fauna. Benthos (surface: $0.1 \mathrm{~m}^{2}$, depth: $20 \mathrm{~cm}, \mathrm{n}$ : 3 samples per pond) was also sampled. Surviving sole from both ponds were compared in terms of number (survival rate), mean growth (mean body length), recent otolith growth (mean increment width), condition factor $K$ and lipid reserves (triaglycerol/sterol ratio TG/ST, according to Galois et al. 1990). Fulton morphometric condition factor $K$ $\left(\mathrm{mg} \mathrm{mm}^{-3}\right)$ was calculated as follow:

$$
K=100\left(W / a L^{3}\right)
$$

where $\mathrm{W}=$ wet weight $(\mathrm{mg}), \mathrm{L}=$ standard length $(\mathrm{mm}), \mathrm{a}=$ species specific constant.

\subsection{Sea surveys}

\section{In situ observations}

Monitored nurseries (depth 5 to $30 \mathrm{~m}$ ) were selected according to their biological importance (Désaunay et al. 1981; Le Pape et al. 2003c) and to their assumed level of exposure to the Erika oil spill (Fig. 3). According to Chantereau et al. (2002) and web site http: //www . ifremer. fr/envlit/surveillance/ERIKA.htm the most visibly polluted areas were situated between the Morbihan coast and the Island of Noirmoutier, with higher and long-lasting bivalve contamination in the Bay of Vilaine (site 1), Loire estuary (site 2) and Bay of Bourgneuf (site 3). These three sites are major nursery areas for sole in northern Bay of Biscay. Conversely, more southern nursery areas such as Pertuis Breton (site 4), Pertuis d'Antioche (site 5) and Gironde estuary (site 6) were considered as non-oiled sites.

In February 2000, survey cruises were aimed at revealing potential short-term effects on fish condition and distribution as well as at evaluating the associated fauna. In June and July, the goal was to verify the settlement of young of the year on the nursery grounds. In September, the condition on the nurseries (fish and invertebrate communities, demography, abundance, growth per year class) was more specifically examined. This monitoring was repeated in September 2001 and 2002.

Samplings (protocols manual Désaunay and Guérault 2002) were performed with a beam trawl (width: $2.5 \mathrm{~m}$; height: $0.5 \mathrm{~m}$ ) with a stretched mesh size of $20 \mathrm{~mm}$ in the cod end. Each sampling at a speed of 2.7 knots covered 4500 to $5000 \mathrm{~m}^{2}$. In 5 cruises a total of 488 hauls were conducted.

The descriptors used to characterise the sole population were occurrence per site, distribution in age and size, abundance (number of individual perha) with no correction for catchability, presence of necrosis or malformation.

\section{Biological analysis (0-group)}

In September 2000, 2001 and 2002 various morphometric and growth-related indices were evaluated on seven month-old animals. For each haul, individuals were immediately frozen at $-20^{\circ} \mathrm{C}(193,175$ and 215 individuals in respective years). Fish size ranged from 6 to $13 \mathrm{~cm}$. Fulton morphometric condition factor $K\left(\mathrm{mg} \mathrm{mm}^{-3}\right)$ was calculated. Otoliths were examined using the technique described in Gilliers et al. (in prep.) and taking into account the fact that the readable portion at the fringes of the otolith is restricted to the last 10 days (Suthers 1998). The estimation of recent growth RG is given by the average increment width $(\mu \mathrm{m})$, as an indication of the somatic growth (Karakiri et al. 1989; Sogard and Able 1992). Variance analysis and Tukey tests were applied to check for inter sites differences in $\mathrm{K}$ and $\mathrm{RG}$ indices.

\section{Ecotoxicology}

\section{Polycyclic aromatic hydrocarbons (PAH)}

During the sea surveys carried out in February, July and September 2000, in September 2001 and in September 2002, 
Table 2. Fuel to water ratios and PAH concentrations in liver and white muscle (dry tissues; 10 fishes were pooled and 1 analysis performed on each pool). The summed PAH are the following: phenanthrene, fluoranthene, pyrene, benz(a)anthracene, chrysene+triphenylene, benzo(b)fluoranthene, benzo(j)fluoranthene benzo(k)fluoranthene, benzo(a)pyrene, dibenz(a,h)anthracene + dibenz(a,c)anthracene, benzo(g,h,i)perylene, indeno(1,2,3-cd)pyrene.

\begin{tabular}{ccccccc}
\hline & $\begin{array}{c}\text { Temperature } \\
\left({ }^{\circ} \mathrm{C}\right)\end{array}$ & Control & $\begin{array}{c}1 / 2000 \\
(\mathrm{vol} / \mathrm{vol})\end{array}$ & $\begin{array}{c}1 / 1000 \\
(\mathrm{vol} / \mathrm{vol})\end{array}$ & $\begin{array}{c}1 / 200 \\
(\mathrm{vol} / \mathrm{vol})\end{array}$ & $\begin{array}{c}1 / 100 \\
(\mathrm{vol} / \mathrm{vol})\end{array}$ \\
\hline $\begin{array}{c}\text { PAH in } \\
\text { liver } \\
\left(\mathrm{ng} \mathrm{g}^{-1}\right)\end{array}$ & 5 & 22 & 57 & 99 & 250 & - \\
\hline $\begin{array}{c}\text { PAH in } \\
\text { white muscle } \\
\left(\mathrm{ng} \mathrm{g}^{-1}\right)\end{array}$ & 15 & 15 & - & 109 & 79 & 171 \\
\hline
\end{tabular}

a piece of white muscle was dissected from 10 fish (1-group, born in March of the previous year) and immediately stored at $-80{ }^{\circ} \mathrm{C}$. In the laboratory, samples were lyophilised and ground before extraction. PAH's were extracted from freezedried solid matrices by microwave assisted extraction with dichloromethane followed by filtration on clean glass cotton (Budzinski et al. 1995). Extracts were then purified on alumina $\left(\mathrm{Al}_{2} \mathrm{O}_{3}\right)$ and silica $\left(\mathrm{SiO}_{2}\right)$ columns and analysed by GC/MS using single ion monitoring mode (Budzinski et al. 1999). $\mathrm{PAH}$ were quantified by internal standard quantification using perdeuterated PAH (Baumard and Budzinski 1997).

\section{Biomarkers (EROD)}

Liver ethoxyresorufine-O-deethylase (EROD) activity was determined as described above (Galgani and Payne 1991). At each of field site 1 to 4,10 individuals of about the same size (1-group, 18-22 cm) were analysed. Samples were collected during the three 2000 cruises (February, July and September).

\section{DNA adducts}

The analytical protocols can be found in Akcha et al. (2003). ${ }^{32}$ P-post-labelled DNA adducts were measured from blood samples and separation was achieved by thin-layer chromatography on PEI cellulose plates. Adduct profiles were analysed qualitatively and semi-quantitatively by autoradiography of the plates, using a radioanalytical system of image analysis. DNA adduct levels were expressed as the number of adducts per $10^{9}$ normal nucleotides. Samples were collected during the three 2000 cruises (February, July and September) at the same sites as EROD analysis.

\section{Results}

\subsection{Laboratory experimental phase}

\section{Tissue contamination}

Although PAH's are metabolised by fish (Budzinski et al. 2004), PAH concentrations were measured in muscle and liver as an indication of immediate contamination. Table 2 summarises the $\mathrm{PAH}$ concentrations in muscle and liver in the various experimental conditions. While tissues PAH

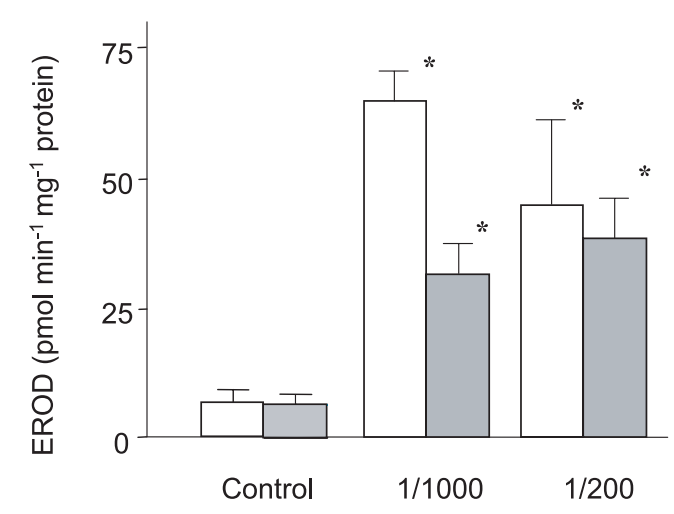

Fuel to water ratio (vol/ vol)

Fig. 4. EROD activity in liver of sole following a 5-day exposure to fuel \#2. White boxes: $5{ }^{\circ} \mathrm{C}$; grey boxes: $15^{\circ} \mathrm{C}$. Values are mean \pm SD from 3 pools of 2 individuals. Asterisks indicate significant differences from corresponding controls $(p<0.01)$.

concentrations increased with fuel exposure, increasing water temperature resulted in relatively lower tissue levels. This is contradictory to what one might have expected since higher temperature should have meant higher solubility of hydrocarbon compounds. However, in warm conditions, a $1 / 1000 \mathrm{fuel} /$ water ratio was enough to attain water saturation in soluble compounds and any additional increase in fuel concentration had not further effect on fish contamination levels (Table 1).

\section{EROD activity}

When compared to the control group, fuel-exposed sole displayed increased liver EROD activity $(\times 10$; Fig. 4). However, the effect of water temperature on the solubility of hydrocarbon compounds precluded the establishing of a relationship between EROD activity and fuel to water ratio or temperature.

\section{Cellular energy charge}

In control fish, white muscle cellular energy charge $([\mathrm{ATP}]+1 / 2[\mathrm{ADP}] /[[\mathrm{ATP}]+[\mathrm{ADP}]+[\mathrm{AMP}]])$ was approximately 0.90 which suggests that cells were energetically in 


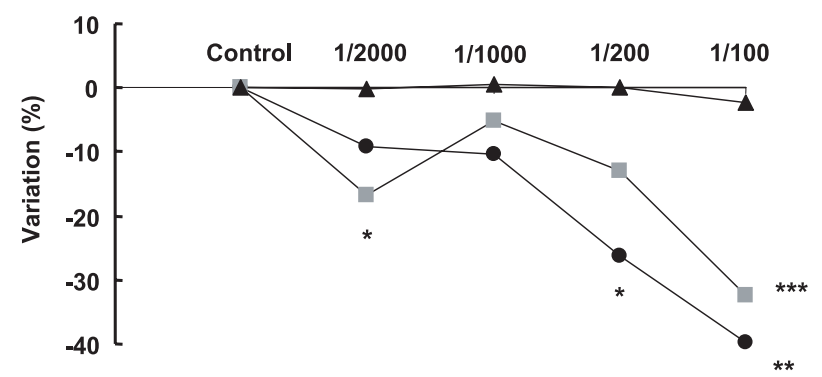

Fig. 5. Effect of a 5-day fuel exposure on cellular energy charge EC (triangles), cellular ATP (circles) and ADP (squares) concentrations. As the absolute values are very different for the 3 variables, results are expressed as variation (\%) by comparison with the corresponding control group. Statistical analysis has been performed on absolute values by comparing contaminated and not-contaminated fish. Each point represents 6 animals. Sign under symbol: * $p<0.05$; $* * p<0.005$; *** $p<0.001$.

good conditions (Fig. 5). This was confirmed by the observation that experimental temperature did not alter this value, demonstrating the efficiency of the pathways regulating energy metabolism. In contaminated fish, exposure to the lower fuel/water ratio (1/2000) had no effect on white muscle fiber energy metabolism. On the other hand, higher doses were associated with significantly reduced ATP and ADP concentrations $(p<0.05)$ as well as with significantly reduced total adenylates concentration $(p<0.05)$. Although statistically significant, the relevance of these alterations remains difficult to establish since the total energy charge remained within narrow limits, even at the highest fuel dose.

A significant relationship between maximum cytochrome oxydase (COX) activity in white muscle and the severity of fuel exposure was observed. The same trend was also found in the heart although not statistically significant. This increase in maximal COX activity with fuel dose suggests a stimulation of aerobic metabolic pathways, which may reflect the metabolisation of contaminants and particularly PAH's (Budzinski et al. 2004).

\section{Gill histology and gill Na,K-ATPase activity}

\section{Gill histology}

Gill histology did not respond uniformly to fuel exposure and a high degree of inter-individual variability was observed (Fig. 6). At the lower dose (1/2000 and 1/1000), 50\% of animals presented lifted epithelium on the secondary lamellae (Fig. 6b) but no alteration of the primary lamellae was observed. At high fuel doses, however, important structural changes were observed resulting in a structural disorganisation of the gills. In these cases $(1 / 200$ and $1 / 100)$, respectively $83 \%$ to $100 \%$ of animals presented alterations of the gill epithelium. We also observed that the severity of the pathologies increased and a thinning down of the primary epithelium was found (Figs. $6 \mathrm{c}$ and $6 \mathrm{~d}$ ). In some cases, aneurysms were observed in the lamellae (Fig. 6c) and we found that the whole of the respiratory epithelium on the secondary lamellae had disappeared (Fig. 6d).
In comparison to control fish we observed no significant difference in the gill $\mathrm{Na}, \mathrm{K}-\mathrm{ATPa} e$ activity of fuel-exposed fish.

\section{Isometric tension of ventricular muscle strips}

Isometric tension produced by electrically stimulated ventricular muscle strips was influenced significantly by exposure to fuel (Fig. 7). When compared to control conditions, strip contractility (frequency $\times$ amplitude) was maintained at the two lowest doses but decreased significantly $(-20 \%)$ at the two higher doses $(p<0.01)$. Moreover, stimulation with adrenaline $\left(10^{-6} \mathrm{M}\right.$ instead of $\left.10^{-9} \mathrm{M}\right)$ showed that the positive inotropic effect of adrenaline was markedly reduced in severely exposed animals, indicating that the ventricular tissue had lost the ability to respond to adrenergic regulation pathways.

\section{Metabolism}

Exposing juvenile sole to fuel (1/200) for five days resulted in a moderate, but significant, reduction in standard metabolic rate and in a more pronounced decrease in active metabolic rate (Fig. 8). The result of these alterations was a $20 \%$ drop in the metabolic scope of fuel-exposed sole. In these individuals we also observed a loss of tolerance to hypoxic conditions. The critical oxygen concentration (minimum water oxygenation required to sustain standard metabolic rate) was $3.5 \mathrm{mg} \mathrm{O}_{2} \mathrm{~L}^{-1}$ in fuel-exposed fish, as opposed to only $2.3 \mathrm{mg} \mathrm{O}_{2} \mathrm{~L}^{-1}$ in control fish.

\subsection{Tidal earthen pond mesocosms}

Faunistic inventory of the samples taken at various stages of the experiment in the earthen ponds showed that from July onward, sediments were colonised by polychaetes and bivalves which constitute the preferred prey of juvenile sole. Mobile macrofauna was dominated by the shrimps Palaemonetes varians and Crangon crangon which, at young stages, may have made a substantial contribution to the soles' diet. A total of $4.9 \mathrm{~kg}$ of macrofauna was obtained from each pond with similar species diversity and abundance. In terms of environmental conditions these ponds are very similar to the natural milieu and no food limitation was detected. Moreover, these mesocosms are characterised by the absence of predators (except the crab Carcinus maenas) and by sheltered hydrodynamics.

\section{Experiment 1: Growth rate of juvenile sole $(17-25 \mathrm{~cm})$ exposed to $1 / 200$ fuel for 5 days}

After 3 months in the tidal ponds, the growth of fuelexposed juvenile sole from 1-group and 2-group was only half that of the control fish (Table 3 ). When the same fish were examined 6-months' post-contamination, no recovery was recorded and growth rates of contaminated fish were still half that of the control fish. 

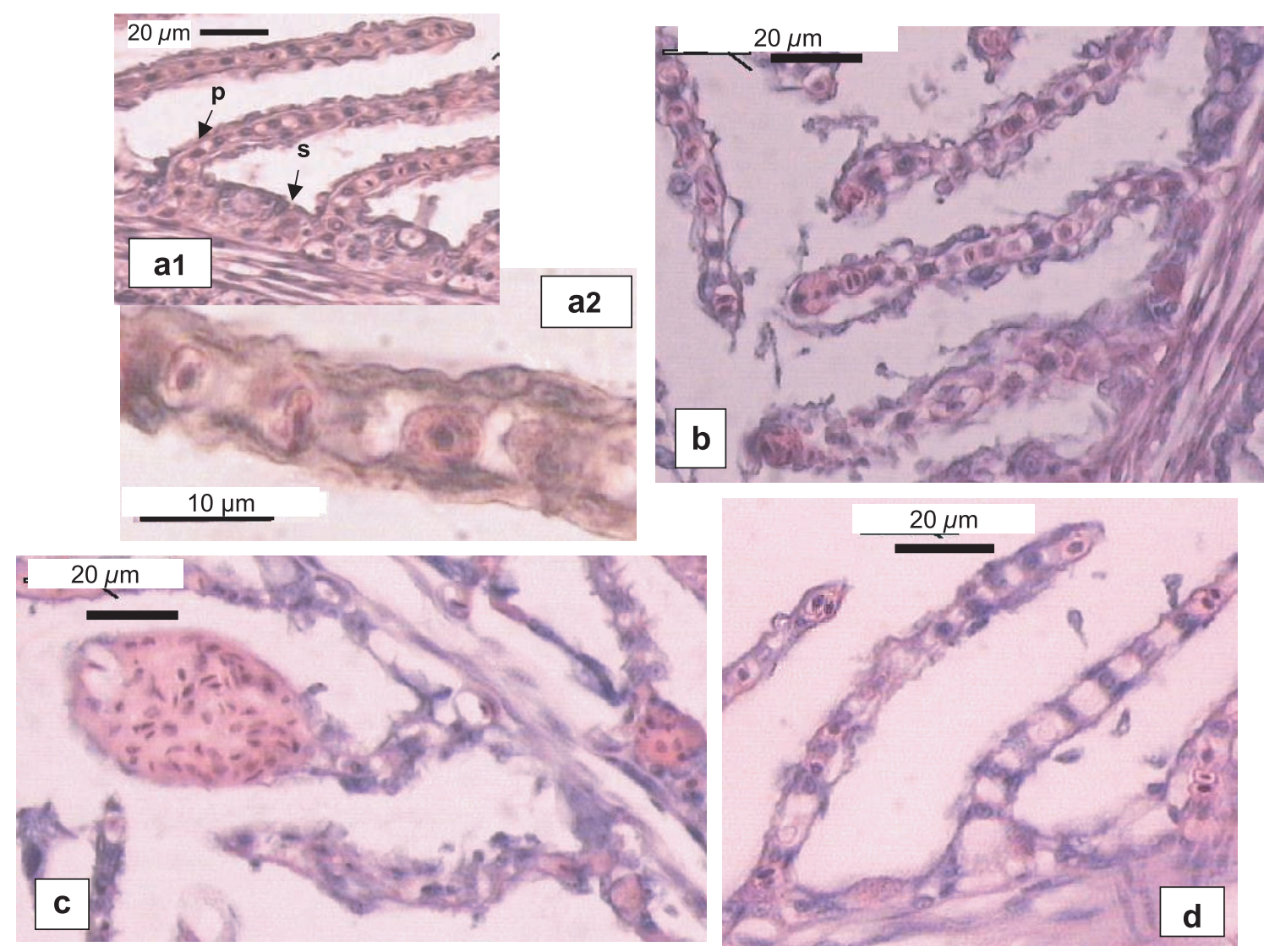

Fig. 6. Effect of a 5-day fuel exposure on gill epithelium. a1: control, normal primary (p) and secondary lamellae (s) H \& E, obj.40. a2: control, H \& E, obj. 100. Architecture of secondary lamellae. b: 1/1000: Epithelial lifting of secondary lamellae, H \& E, obj.40. c: 1/200; Aneurysm of secondary epithelia and thinning of primary epithelium, $\mathrm{H} \& \mathrm{E}$, obj.40. d: 1/100 disappearance of the secondary epithelium without inflammatory foci.

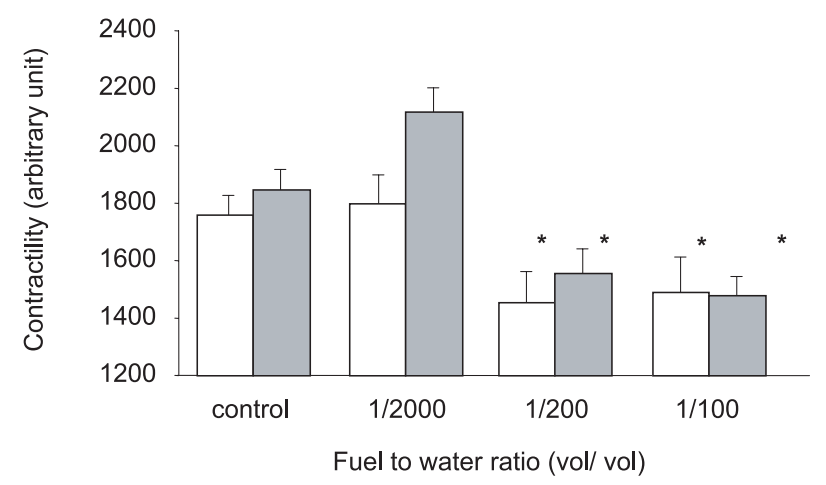

Fig. 7. Pumping capacity (relative isometric tension $\times$ response frequency) in stimulated ventricular strips from sole after a 5-day exposure to fuel \#2. White boxes: [adrenaline] $=10^{-9} \mathrm{M}(n=10)$; grey boxes: [adrenaline] $=10^{-6} \mathrm{M}(n=10)$. Asterisks indicate significant differences from corresponding controls $(p<0.05)$.

\section{Experiment 2: Growth and condition factor of juvenile sole $(6-10 \mathrm{~cm})$ exposed to $1 / 1000$ fuel for 24 hours}

One day after exposure to fuel, 45 fish from the fuelexposed group died, against 27 control fish. These death rates integrate the delayed effect of capture and manipulation but also possibly indicate an immediate effect $(6 \%$ additive mortality) of the contamination by hydrocarbons. At the end of the 3 month period in the mesocosms, survival was $32.9 \%$ in the fuel-exposed group and $53.9 \%$ in the control group (Table 3). For comparison, Table 3 also reports the growth rate of juvenile sole measured in their habitat of origin (Vilaine estuary) during the same time period. From an initial length of $7.9 \pm 0.2 \mathrm{~cm}$, the control group in the ponds reached $12 \mathrm{~cm}$ after two months whereas, in the meantime, 0-group sole reached $12.0 \pm 0.2 \mathrm{~cm}$ on their natural nursery. After two months in the mesocosms, fuel-exposed fish were significantly smaller $(10.6 \pm 0.5 \mathrm{~cm})$. This difference in growth performance was maintained and in October, the mean length of fuel-exposed sole was $10.8 \pm 0.3 \mathrm{~cm}$ against $12.3 \pm 0.3 \mathrm{~cm}$ in the control fish. This negative effect of fuel exposure was confirmed by the condition factor which was significantly lower $\left(1.11 \pm 0.23 \mathrm{mg} \mathrm{mm}^{-3}, n=34\right)$ in fuel-exposed fish than in control fish $\left(1.30 \pm 0.28 \mathrm{mg} \mathrm{mm}^{-3}, n=44\right)$. Likewise, recent growth rate estimated by otolith examination was less in fuelexposed individuals than in control animals $\left(4.1 \pm 0.7 \mu \mathrm{m} \mathrm{d}^{-1}\right.$, $n=34$ and $6.7 \pm 1.0 \mu \mathrm{m} \mathrm{d}^{-1}$ respectively, $\left.n=44\right)$.

The measurements of the level of lipid energy reserves associated (triacylglycerols) revealed further evidence of poor condition in the exposed sole, where the ratio of triacylglycerols to sterols was very low $(0.06, \mathrm{cv}=46.6, n=15)$ when compared to that of control fish $(2.34, \mathrm{cv}=22.1, n=15)$. 
Table 3. Number, size and growth of control and fuel-exposed sole before and after a 59-day (0-group) or 182-day (1- and 2-groups) residence in the tidal earthen mesocosms. For comparison, data for growth performance of juvenile sole in the Vilaine estuary (site 1; Fig. 3) over the same interval are also shown. Growth values for 0-group were estimated by subtracting mean initial length from mean final length and dividing by time. $N$ : number of experimental fish, $n$ : sample size.

\begin{tabular}{ccccc}
\hline & \multicolumn{3}{c}{ 0-group } & \multicolumn{2}{c}{ 1-2-groups } \\
\cline { 2 - 5 } & Control & $\begin{array}{c}\text { Exposed } \\
(1 / 1000-24 \mathrm{~h})\end{array}$ & $\begin{array}{c}\text { Vilaine } \\
\text { Estuary }\end{array}$ & $\begin{array}{c}\text { Exposed } \\
(1 / 200-5 \text { days })\end{array}$ \\
\hline$N$ & 266 & 253 & 60 & $18.3 \pm 0.6$ \\
\hline $\begin{array}{c}\text { Initial Length } \\
(\mathrm{cm})\end{array}$ & $\begin{array}{c}7.9 \pm 0.2 \\
n=115\end{array}$ & $25.9 \pm 0.7$ & $22.3 \pm 0.8$ \\
\hline $\begin{array}{c}\text { Final Length } \\
(\mathrm{cm})\end{array}$ & $\begin{array}{c}12.0 \pm 0.4 \\
n=30\end{array}$ & $0.6 \pm 0.5$ & $12.0 \pm 0.2$ \\
\hline $\begin{array}{c}\text { Growth rate } \\
\left(\mathrm{mm} \mathrm{d}^{-1}\right)\end{array}$ & 0.70 & 0.45 & 0.65 & $0.42 \pm 0.04$ \\
\hline
\end{tabular}
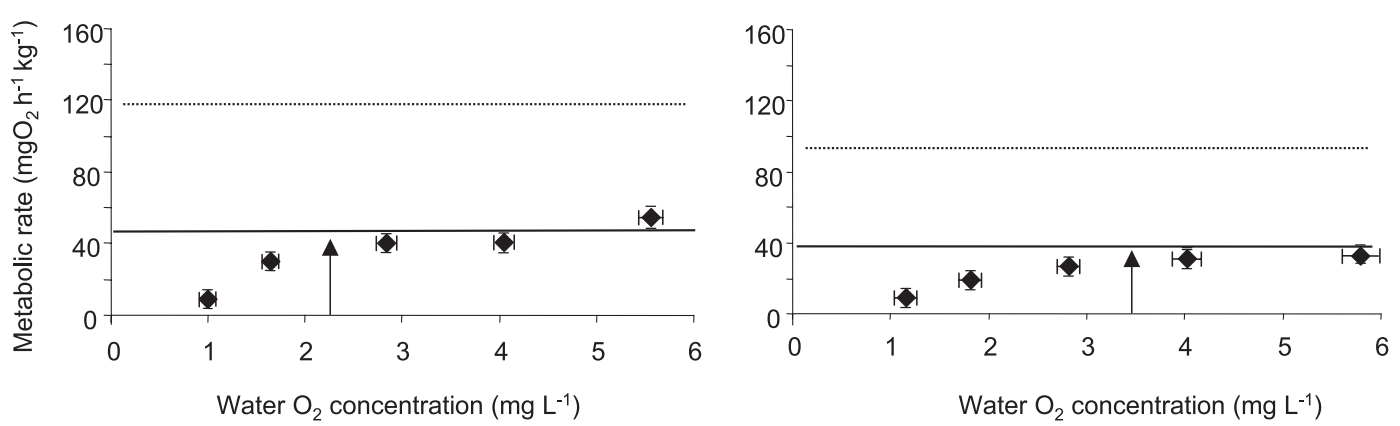

Fig. 8. Effect of a 5-day fuel exposure on metabolism. Left panel; control fish $(n=8)$, right panel, fuel exposed fish $(1 / 200 \mathrm{vol} / \mathrm{vol} ; n=8)$. Diamonds: routine oxygen consumption; solid lines: standard metabolic rate; dotted lines: active metabolic rate; arrows: critical water oxygen concentration.

This indicates that the exposed animals were in very poor nutritional condition, and presumably had experienced serious bioenergetic limitations in the semi-natural environment provided by the mesocosm.

\subsection{Sea surveys}

\section{In situ observations}

In February 2000, trawl surveys revealed the presence of fuel near the bottom in 18 of the 48 hauls in the Vilaine Estuary (site 1) and Bourgneuf Bay (site 3), with at least one ball of fuel collected in the net or fuel spots staining the net. The presence of moribund endobenthic invertebrates was noticed at the three oiled sites (e.g., self-opening shells of bivalves Mactra stultorum, Pharus legumen and echinoderms Echinocardium cordatum, in quantities up to several hundred individuals per haul). Such observations are quite uncommon in trawl catches and they are a symptom of alteration in the benthic community. The most common fish species (Solea solea, Merlangius merlangus, Trisopterus luscus, Platichthys flesus, etc.) were found in the hauls and we observed no malformation, necrosis or stain that could be attributed to fuel. As expected, fish from 1-group (hatched during spring 1999) were dominant in the samplings. The distribution of the cohort of sole along the inshore-offshore gradient was as expected from previous surveys (Dorel et al. 1991). This observation suggests that during their inshore migration, young fish did not avoid polluted areas.

During the June-July 2000 survey, only one haul out of 69 showed the presence of fuel at a depth of $15 \mathrm{~m}$. No anomaly was observed with regard to invertebrates with the exception of the sea urchin E. cordatum which remained abundant in trawl catches in the Loire estuary. Fish populations displayed expected abundance and distribution patterns. The first observations of the year class 2000 of sole were made in June-July in the Vilaine Estuary and Bourgneuf Bay (Table 4). The presence of this year class proves that some successful spawning occurred in 2000. The settlement of juveniles on the inshore nursery grounds was viewed as normal.

In September 2000, 2001 and 2002, the occurrences of 0 -group fish were high in all sites. Fish densities were variable but within the range of classically reported natural variation. Comparing the mean total length (TL) of 0-group sole near the end of their first growing season was made under the assumption that the contamination of northern Bay of Biscay nurseries by oil altered the growth of juveniles. However, comparisons of the size composition among nurseries revealed a south to north positive gradient. This gradient was also found in September 2003 (Désaunay, pers. com.). 
Table 4. Occurrence (\% of presence in hauls) and density (number of individuals per hectare) of 0-group sole caught during the 2000, 2001 and 2002 cruises. TL: mean total length $(\mathrm{cm})$, SD: Standard deviation $(\mathrm{cm})$, n: number of individuals. In June-July, the mean length was biased by the mesh size $(20 \mathrm{~mm})$, and the standard deviation was not calculated.

\begin{tabular}{|c|c|c|c|c|c|}
\hline \multicolumn{2}{|c|}{ Date / site } & \multirow{2}{*}{$\begin{array}{c}\text { Vilaine } \\
28.7\end{array}$} & \multirow{2}{*}{$\begin{array}{c}\text { Loire } \\
0\end{array}$} & \multirow{2}{*}{$\begin{array}{c}\text { Bourgneuf } \\
37.5\end{array}$} & \multirow{2}{*}{$\begin{array}{c}\text { P. Breton } \\
11.1\end{array}$} \\
\hline & Occ\% & & & & \\
\hline June-July & Density & 12.0 & 0 & 15.1 & 0.3 \\
\hline \multirow[t]{3}{*}{2000} & $\mathrm{TL}$ & 7.6 & - & 6.8 & 6.0 \\
\hline & $\mathrm{n}$ & 120 & 0 & 52 & 1 \\
\hline & Occ\% & 54.5 & 68.2 & 71.4 & 55.6 \\
\hline September & Density & 61.7 & 10.6 & 79.8 & 137.7 \\
\hline \multirow[t]{4}{*}{2000} & $\mathrm{TL}$ & 12.8 & 11.6 & 10.0 & 11.5 \\
\hline & SD & 1.4 & 1.35 & 1.1 & 1.2 \\
\hline & $\mathrm{n}$ & 759 & 86 & 635 & 937 \\
\hline & Occ $\%$ & 65.9 & 42.1 & 53.3 & 50.0 \\
\hline September & Density & 32.0 & 17.0 & 15.0 & 12.5 \\
\hline \multirow[t]{4}{*}{2001} & $\mathrm{TL}$ & 13.0 & 11.7 & 10.9 & 10.7 \\
\hline & SD & 1.8 & 1.1 & 1.2 & 1.6 \\
\hline & $\mathrm{n}$ & 483 & 117 & 802 & 99 \\
\hline & Occ $\%$ & 60.0 & 58.8 & 54.5 & 36.4 \\
\hline September & Density & 44.5 & 6.5 & 47.0 & 19.9 \\
\hline \multirow[t]{3}{*}{2002} & $\mathrm{TL}$ & 12.0 & 11.6 & 10.6 & 10.5 \\
\hline & SD & 1.4 & 2.1 & 1.5 & 1.3 \\
\hline & $\mathrm{n}$ & 306 & 68 & 178 & 76 \\
\hline
\end{tabular}

Table 5. Analysis of variance of condition index $\mathrm{K}\left(\mathrm{mg} \mathrm{mm}^{-1}\right)$ and recent otolith growth $\mathrm{RG}(\mu \mathrm{m})$ for the six studied sites over the three years in question.

\begin{tabular}{ccccrcc}
\hline Year & $n$ & Source & df & \multicolumn{1}{c}{ SS } & \multicolumn{1}{c}{ F } & $p$-value \\
\hline 2000 & 193 & K & 5 & 0.264 & 5.782 & 0 \\
& & RG & 5 & 48.176 & 5.377 & 0 \\
2001 & 175 & K & 5 & 0.159 & 1.497 & 0.19 \\
& & RG & 5 & 95.361 & 28.113 & 0 \\
2002 & \multirow{2}{*}{215} & K & 5 & 0.398 & 8.268 & 0 \\
& & RG & 5 & 140.809 & 46.390 & 0 \\
\hline
\end{tabular}

\section{Biological analysis (0-group)}

Significant differences in the condition factor $(\mathrm{K})$ were found among the 6 survey sites (Table 5) in 2000 and 2002 but not in 2001 (Fig. 9). Nevertheless, a posteriori multiple comparison applied to 2000 and 2002 revealed that $\mathrm{K}$ in the most southern sites $(4,5,6)$ were significantly lower than in the oiled northern sites $(1,2,3)$.

Recent growth of juvenile sole varied significantly among the six nurseries (Table 5 and Fig. 10) in accordance with the latitudinal gradient of body size mentioned above. Multiple comparison analysis indicated that the survey sites could be sorted into two batches, which were significantly different. Northern sites (sites 1,2 and 3) were exposed to the oil and sole growth performances on these sites were similar.
Southern sites (sites 4, 5 and 6) on the other hand displayed lower growth rate and this for all 3 years.

\section{Ecotoxicology \\ Polycyclic aromatic hydrocarbons (PAH) in fish}

The accumulation of PAH in the tissues (white muscle) of sole sampled on the various field site was relatively limited (Fig. 11). PAH are hydrophobic compounds that accumulate in fat and lipid structures such as cellular membranes. However, PAH are also metabolised through specific pathways (Budzinski et al. 2004). The trend displayed by PAH concentration in sole from all sites suggests a chronic exposure to $\mathrm{PAH}$ but these data alone do not provide a conclusive link between such contamination and the Erika oil spill. On the other hand, the monitoring of bile metabolites did reveal exposure of the fish to Erika fuel (Budzinski et al. 2004). Moreover, the distribution and origin of PAH along the French Atlantic coast (Chantereau et al. 2002) suggests an impact of the oil spill on the nurseries, with specific sites (1 and 2 ) having marked petrogenic characteristics. Nevertheless, the measured concentration of PAH in oiled and non oiled sites are generally low and close to the values observed in the control fish of the experimental phase $\left(8 \mathrm{ng} \mathrm{g}^{-1}\right)$. A slight increase was observed in September 2001 in oiled sites. This could be interpreted as an accumulation linked to longer exposure to a polluted environment (individuals sampled in September 2001 experienced this environment for 18 months, whereas those collected in September 2000 spent only 8 months in this habitat). 


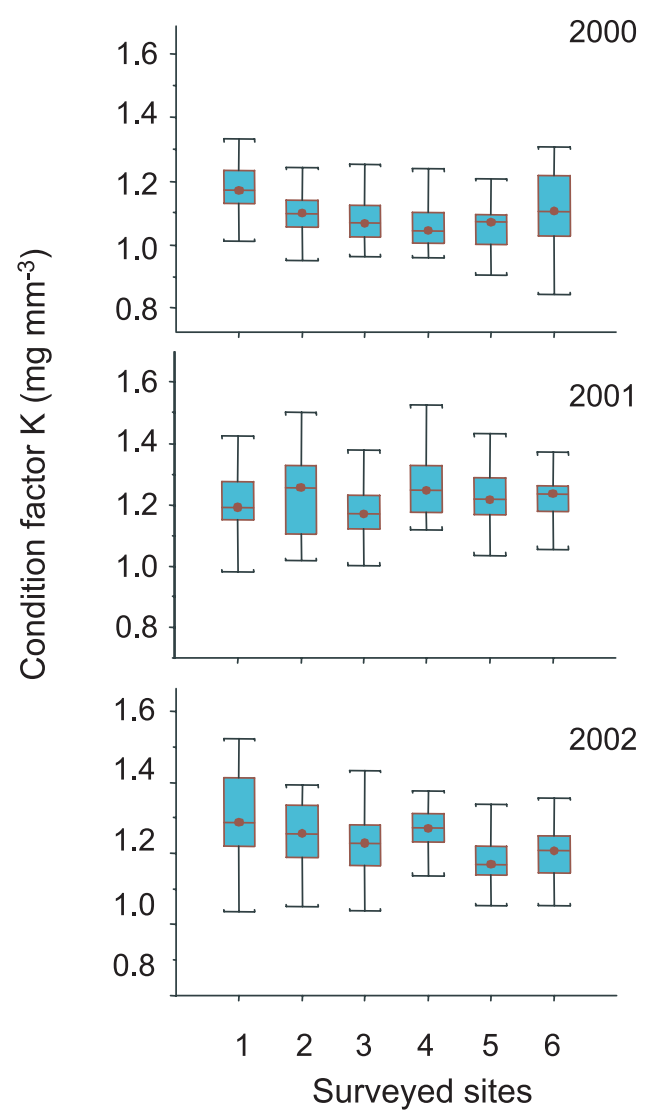

Fig. 9. Index of condition $\left(\mathrm{mg} \mathrm{mm}^{-3}\right)$ of 0-group sole at six sites (see Fig. 3) surveyed in 2000, 2001 and 2002. Median value, upper and lower quartile (box), extreme values (line).

\section{Biomarkers (EROD)}

During the February 2000 survey, the highest liver EROD activities were found in fish from Bourgneuf Bay, Vilaine Estuary and Pertuis Breton (Fig. 12). In July 2000, measured EROD activities were greatly reduced in all of the sites with the exception of the Vilaine Estuary where intense detoxification activities were still found. In September 2000 we found no significant difference between sites.

\section{DNA adducts}

The number of adducts was generally higher in February at Erika polluted sites. In the Bourgneuf Bay, the number of adducts reached a peak of 70 adducts $10^{-9}$ nucleotides in July (Fig. 12). In the Loire estuary and the Bay of Vilaine, high values are observed in February (respectively 50 and 30 adducts $10^{-9}$ nucleotides) but they decreased steeply in July and September. In the Pertuis Breton, the number of adducts remained low, at around 20 adducts $10^{-9}$ nucleotides. No significant correlation was found between EROD activity and DNA adducts $\left(R^{2}=0.048\right)$. None of these variables were correlated with PAH levels in the muscle (respectively $R^{2}=0.008$ and 0.028).

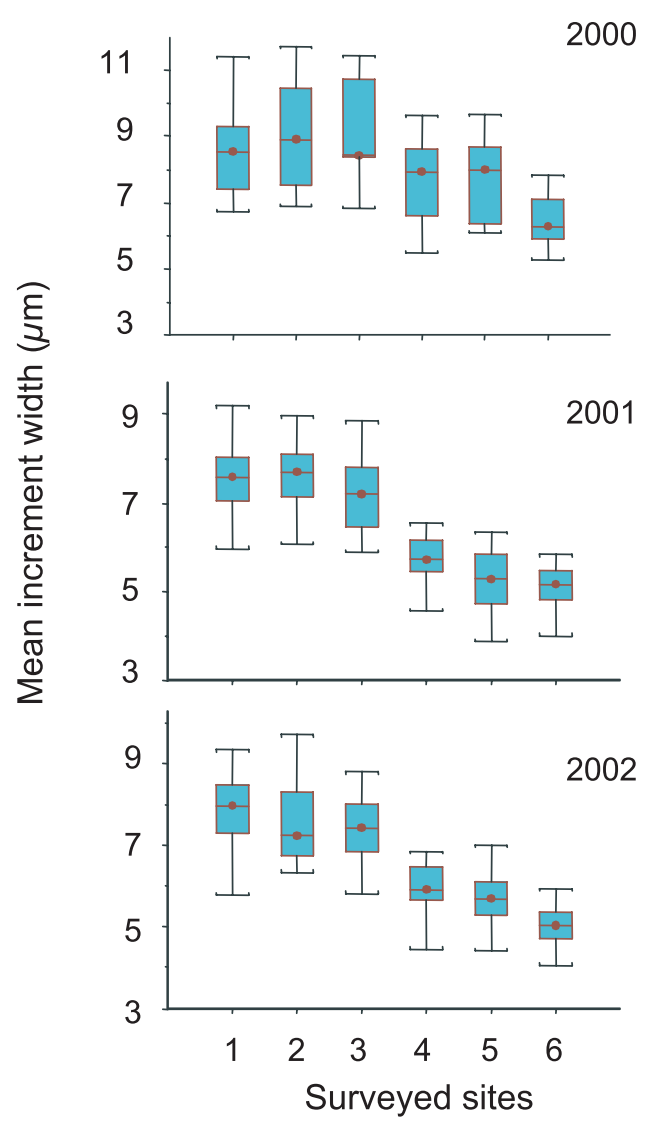

Fig. 10. Index of recent otolith growth $(\mu \mathrm{m})$ of 0 -group sole at six (see Fig. 3) sites surveyed in 2000, 2001 and 2002. Median value, upper and lower quartile (box), extreme values (line).

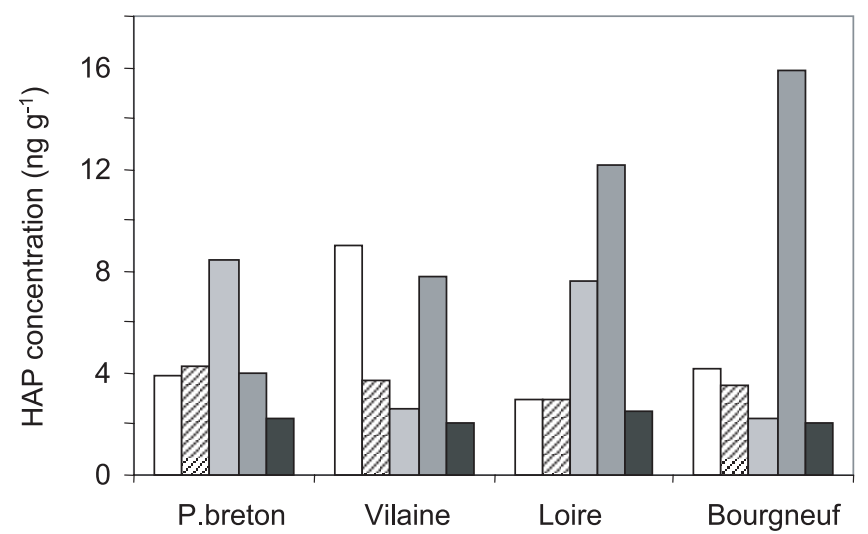

Fig. 11. PAH concentration (sum of 12 of the 16 priority $\mathrm{PAH}$ of the EPA, in ng.g-1 of dry matter) in the white muscle of sole collected at four sites during three cruises: February 2000 (white boxes), August 2000 (stripped box), September 2000 (light grey boxes), September 2001 (dark grey boxes) and September 2002 (black boxes). Each box corresponds to a pool of 10 individuals. The summed PAHs are the following: phenanthrene, fluoranthene, pyrene, benz(a)anthracene, chrysene+triphenylene, benzo(b)fluoranthene, benzo(j)fluoranthene, benzo(k)fluoranthene, benzo(a)pyrene, dibenz(a,h)anthracene $+\operatorname{dibenz}(\mathrm{a}, \mathrm{c})$ anthracene, benzo(g,h,i)perylene, indeno(1,2,3-cd)pyrene. 


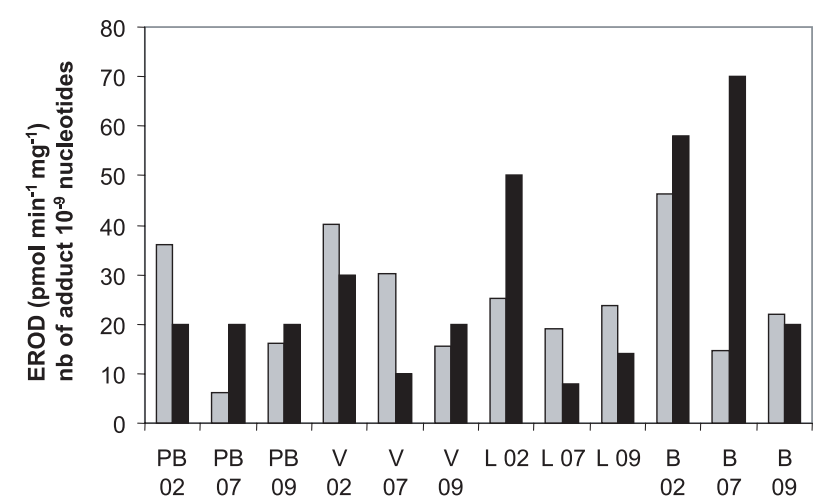

Fig. 12. EROD activity (grey boxes) and DNA adducts (black boxes) in liver from sole collected during three 2000 cruises $(02,07,09)$ at four sites: Pertuis Breton (PB), Bay of Vilaine (V), Loire Estuary (L) and Bourgneuf Bay (B).

\section{Discussion}

Numerous examinations of the ecological consequences of the Erika oil spill (this volume) demonstrate an impact at the ecosystem level. Benthos on the intertidal and subtidal zones displayed noticeable mortalities (Barillé-Boyer et al. 2004) and bird species were heavily impacted, particularly diving birds (Bretagnolle et al. 2004). Earlier experimental exposures of fish to PAH essentially examined the effects of contamination through feeding (Carls et al. 1996 in Hilborn 1996) or after contact with oiled sediments (Moles et al. 1994). In the present case, and in order to mimic what were believed to be the conditions of contamination in natura, we focused our investigation on the effects of the soluble phase.

The examination of the consequences of the Erika oil spill for sole populations required that the successive stages of the species' early life cycle be considered (Koutsikopoulos et al. 1995). The acute phase of the pollution (January to March 2000) was synchronous with the aggregation of adults on the spawning grounds (depth 40 to $100 \mathrm{~m}$; Koutsikopoulos and Lacroix 1992) and the subsequent pelagic stages, eggs and larvae (Amara et al. 1993). From April to October, the pollution was more diffuse and this phase of the contamination corresponded with the transition from pelagic to benthic life (Amara et al. 2000) and the concentration of juveniles in estuaries and shallow nurseries (Dorel et al. 1991). To make a full description of the context prevailing at the time of the spill, it is also important to mention that it happened together with a series of remarkable storms that affected the whole of the French Atlantic coast from December 26th to 28th 1999. The consequences of the massive arrival of oil slicks in coastal areas summated with these exceptional hydrodynamic conditions, with a tide level $2 \mathrm{~m}$ higher than usual.

\subsection{Biological integration levels, adaptation and integrative approach}

The level of fitness of an animal results from its ability to maintain a dynamic equilibrium between environmental constraints and its specific biological requirements. The triptych morphology-physiology-biochemistry sets the functional framework within which adaptation can take place. We viewed it as essential, therefore, to examine the effects of hydrocarbons on the main organs and physiological processes involved in adaptation. To ensure that this examination provided the basis for an ecological interpretation of the consequences of the spill, it was also important that the series of interactions linking the various levels of biological organisation be taken into consideration (Fig. 1).

Our study integrated 3 complementary approaches. The first aspect aimed at describing the effects of fuel exposure on the physiological, biochemical and energetic processes involved in adaptation. During that experimental phase of the work, fish contamination was assessed through the examination of the kinetics of absorption, accumulation and metabolisation of PAH, as well as via the measure of liver EROD activity and of the number of cytogenetic lesions. Mesocosm experiments allowed testing of the long-term effects of these functional and morphological alterations on fish ecological performance (survival and growth). Finally, field surveys extended our grasp of that complex system by laying the foundation for an ecosystemic interpretation of the consequences of the Erika oil spill.

\subsection{Experimental phase}

\section{Contamination and role of the dissolved phase}

The conditions of experimental exposure (fuel concentration and duration) had to be decided before field data on PAH composition and concentration in the water column were available (Tronczynski et al. 2004). Moreover, at that time no information concerning the metabolisation of PAH in sole was at hand (Budzinski et al. 2004).

A posteriori information (Tronczynski et al. 2004) provided an estimate of aqueous 16 EPA priority parent PAH concentrations in the coastal waters at sites 1 and 2. During that 2-year survey (2000-2002), in situ water samples displayed values ranging from $8.75 \mathrm{ng} \mathrm{L}^{-1}$ to $20.94 \mathrm{ng} \mathrm{L}^{-1}$. These values are consistent with the EPA-PAH concentrations found in the soluble phase during our experimental fuel exposures. For instance, at $15^{\circ} \mathrm{C}$, a medium dose of exposure $(1 / 1000)$ yield to a EPA-PAH concentration of $70 \mathrm{ng} \mathrm{L}^{-1}$ (Table 2). This value is 3 to 8 times what was measured in natura several months after the landfall of fuel and it is therefore likely to be representative of the contamination conditions that prevailed during the first weeks following the spill.

It must be underlined that during the experimental laboratory phase of ECTOPHY, very few fish died during or immediately after being exposed to fuel (6\% in 0-group and less than $0.5 \%$ in older sole). During exposure to fuel there was little contact between fish buried in the sand and oil floating on the surface, although less soluble portions of the fuel may have drifted to the bottom and accumulated in the sediment. The functional alterations observed at the end of the various exposures therefore suggest that fuel solubility is an essential element when assessing the level of risk from contamination. This result also support the view that the presence, or absence, of dead fish on beaches is not an adequate means to evaluate the severity of an oil spill, and even more so if the generally 
rapid intervention of scavengers is taken into consideration. Because fish were not fed during exposure to fuel, we considered that dietary intake was negligible and that the most likely route of contamination was through dissolved compounds diffusing into the fish across their epithelia.

Our results clearly show a relationship between the level of saturation of the water with PAH and their concentrations in fish tissues. However, when full saturation of the water was reached, increasing the amount of hydrocarbons in the environment had no impact on tissues PAH levels. This observation, together with the fact that PAH are readily metabolised (Budzinski et al. 2004), suggest that tissue PAH levels are not adequate indicators of contamination in fish.

\section{Functional and morphological disruptions}

During the experimental phase, the contamination of juvenile sole was revealed by the increased EROD activity and PAH concentrations in liver and white muscle. This contamination was associated with morphological and functional alterations that affected the organs and processes involved in adaptation. A progressive disruption of gill epithelium with fuel dose was also reported by Mallatt (1985). However, the functional consequences of these alterations remain to be established. Despite the fact that reduced metabolic scope and cellular adenylate content suggest possibly impaired oxygen diffusion at the gill, the maintenance of Na,K-ATPase activity suggests that osmoregulatory ability was preserved.

In addition to the reduced cellular adenylate content, two further elements strengthen the hypothesis of disrupted metabolism. First, we observed that increased fuel dose was associated with increased cytochrome $\mathrm{C}$ oxydase (COX) activity in the white muscle. COX controls electron transfer along the mitochondrial respiratory chain and hence is a key site for modulation of metabolic energy production by oxidative phosphorylation. An increased activity of this enzyme complex obviously suggests increased metabolic demand most probably in relation with detoxification-related activities. The second element relates to the reduced pumping capacity of the myocardium and its impaired adrenergic regulation pathways. The cardio-vascular system is known to play a critical role in adaptation (for a recent review see Gamperl and Farrell 2004) and the current findings support our view that fuel exposure results in morphological and functional impairments that combine to reduce the ability of fish to respond to environmental perturbations or poor conditions.

\section{Environmental adaptation}

It is striking that the functional and morphological disruptions described above were associated with a very significant decrease in aerobic metabolic scope. Metabolic scope is an integrated measure of the energy resources that an animal can mobilise for routine function. The $20 \%$ reduction in aerobic metabolic scope measured in fuel-exposed fish must be seen as a loss in the animals' energetic flexibility or versatility. In situations associated with high metabolic demand, these contaminated animals will be faced with energy budgeting conflicts which are classically solved at the expense of growth or reproduction and, at a later stage, lead to reduced survival (Priede 1977 and 1985; Claireaux and Largardère 1999; Claireaux et al. 2000). In any environmental gradient, contaminated animals are also likely to suffer from a reduction in their potential habitat, areas with suboptimal conditions becoming physiologically beyond reach and so cannot be colonised successfully.

\subsection{Mesocosm experiments}

Experiments in the tidal earthen ponds established that the various disruptions experienced by juvenile sole following experimental exposure to fuel had long-term consequences for their ecological performance. Reduced survival and growth were observed 3 months after the contamination and no sign of recovery was observed even after 6 months. Moles and Norcross (1998) showed that juvenile flatfish exposed to hydrocarbon-contaminated sediment also displayed reduced growth 1 to 3 months after exposure. More than 4 months after having been exposed to fuel, sole displayed very depressed lipid profiles, with reduced triacylglycerol to sterol ratios, strengthening even further our view that fuel-exposed fish experienced impaired energy metabolism.

\subsection{Ecosystem approach}

\section{Difficulties identified with the diagnosis}

The examination of the abundance of the 2000 year-class $(<$ 1999; Anonymous 2003) and the biological characteristics of the individuals sampled during the various survey cruises revealed no impact of the oil spill on natural sole populations in the Northern Bay of Biscay. The same conclusion also holds for other fish species such as Pleuronectes platessa, Dicologoglossa cuneata, Merlangius merlangus and Mullus surmuletus (Gilliers, pers. obs.). Following the pollution by the "Sea Empress" the same observation was made with regard to the European sea bass Dicentrarchus labrax (Lancaster et al. 1998).

During the year that followed the spill, EROD activity in the liver of captured soles were high in February in Bourgneuf Bay (site 3) and in the Vilaine Estuary (site 1). These areas are confined and were among the most exposed to contamination (Chantereau et al. 2002). The relatively low EROD activity measured in the Loire Estuary ( site 2) can be ascribed to the high river flow at the time of the accident. This, together with the shape of the estuary, prevented the slicks from moving upstream. The induction of EROD activities in Pertuis Breton is unexpected and could be attributed to the storms that hit Western France simultaneously with the oil spill. These exceptional weather and sea conditions may have contributed to the resuspension of contaminants already present in the sediment.

Any diagnosis based on the mean size of the 0-group of sole is unachievable, the apparent size gradient probably being a signature of each local habitat. It has been shown that, at the scale of the Bay of Biscay, each coastal habitat displays a specific performance in terms of potential growth, in relation with local hydroclimate, prey availability and typology (Le Pape et al. 2003d). 


\section{Specificity of the Erika pollution}

Environmental conditions at the time and during the first few months after a hydrocarbon discharge are crucial in determining its ecological impact. The Erika accident occurred in very specific conditions that quickly moved the oil slicks onto the shores, sometimes very high up onto the beaches. This rapid movement of the pollution reduced the duration of the contamination of the subtidal nurseries and other key areas. Moreover, following this relatively short period of acute contamination, favourable climatic conditions during the first half-year of 2000 in the Northern Bay of Biscay may have resulted in more favourable environments that contributed to the survival of contaminated animals. At the scale of the Bay of Biscay, Le Pape et al. (2003a) established a relationship between river flow during winter and the abundance of juveniles on the nurseries the following spring. From that perspective, years 2000 and 2001 were very close to the historical high reported in 1988. For instance in 2000 and 1988, water flow in the River Vilaine was respectively 188 and $229 \mathrm{~m}^{3} \mathrm{~s}^{-1}$. In these years, juvenile sole densities were respectively 99.5 and 85.1 ind.ha $^{-1}$. Conversely, a draught year such as 1997 $\left(52 \mathrm{~m}^{3} \mathrm{~s}^{-1}\right.$ in the winter period) provided a lower density of juvenile sole $\left(15.8\right.$ ind.ha $\left.^{-1}\right)$. This observation suggests that the negative effects of the contamination on sole physiological performance may have been compensated by exceptionally favourable and non-selective conditions that prevailed in 2000 and 2001. That is, those individuals that under normal conditions might not have survived because of impairments to their physiology were able to survive.

\section{Conclusion}

It is clearly established that hydrocarbons influence, directly or indirectly the physiology (Lee et al. 1978; Kiceniuk and Khan 1987; Fletcher et al. 1981; Hontela et al. 1995), health (Köhler and Hölzel 1980; Solangi and Overstreet 1982; Moore and Stegeman 1994; Vethaak and Wester 1996; Vethaak et al. 1996; Marty et al. 1996; Hose et al. 1996), growth (Byrne and Calder 1977; Linden 1978; Fletcher et al. 1981) and reproduction (Berdugo et al. 1977; Truscott et al. 1992; Kocan et al. 1996) of fish (see also Cravédi 2001). On the other hand, the interpretation of these alterations in ecological terms i.e., fitness, is rarely tackled (Connolly 1991). This deficiency is the main reason for our poor ability to predict the long-term ecological consequences of oil spills (Capuzzo 1980; Peterson 2001).

Investigating a complex system requires a multidisciplinary approach that considers the various levels of biological organisation. According to Hilborn (1996), in situ approaches require that a target species, a biological stage and a contamination-free site be identified before inter-site comparison can be made and conclusions drawn. Above all, an accurate understanding of the sources of hydroclimatic variability, and their effects on biological/ecological processes, is essential. The benthic community structure may provide a diagnosis of habitat disturbance. Developing biological indicators for target species is currently a major concern
(Frid et al. 2000). A long period of trials is needed to validate which indicators are the most useful, manageable and efficient (Dale and Beyeler 2001). Our study suggest that the most relevant and easily implemented biological indicators are the condition factor and somatic or otolith growth.

Experimental approaches provide tests to assess the sensitivity of a target species to a given contaminant, particularly when in situ effects cannot be distinguished from the natural variability. It is then crucial to analyse these experimental results from an ecological perspective in order to assess any relevance of the observed functional or morphological alterations. At this investigation scale, histology, energetics and challenge tests are promising approaches that can give an overall view of the ability of an organism to adapt to its environment, this ability being the prime determinant of fitness. Various attempts have been made to reproduce relevant experimental conditions using caged fishes in restricted fjords (Goksoyr et al. 1994) or in lakes (Soimasuo et al. 1995). From that point of view, the tidal earthen mesocosms at CREMA-Ifremer proved to be exceptionally valuable experimental tools. As ecosystem fluctuation is a multifactorial process, it will remain difficult to assign a natural or anthropogenic cause to a given change. However, from both a scientific and management point of view, it is extremely important to accumulate a knowledge base that will permit distinction between natural and man-made variations in ecosystems (Daan et al. 1996).

Acknowledgements. The authors are grateful to Dr D.J. McKenzie for reviewing various aspects of the manuscript. We are also grateful to A. Hillenweck, D. Leguay, A. Mauffret, E. Perdu, P. Pineau, M. Prineau and C. Valotaire for their invaluable technical assistance. We would also like to thank the crew of the R/V "Gwen Drez", all the colleagues that were involved in the cruises, as well as J.-M. Arruabarrena who kindly collected the fish. The current research was funded by "Ministère Français de l'Écologie et du Développement Durable" as part of the program "Suivi des conséquences écologiques et écotoxicologiques de la marée noire due au naufrage de l'Erika". The help and support of the scientific committee in charge of the program is sincerely acknowledged.

\section{References}

Akcha F., Vincent-Hubert F., Pfhol-Leszkowicz A., 2003, Potential value of the comet assay and DNA adduct measurement in dab (Limanda limanda) for assessment of in situ exposure to genotoxic compounds. Mutat. Res. Genet. Toxicol. Environ. Mutagen. 534, 21-32.

Amara R., Lagardère F., Désaunay Y., 1993, Seasonal distribution and duration of the planktonic stage of Dover sole, Solea solea, larvae in the Bay of Biscay: an hypothesis. J. Fish Biol. 43, 17-30.

Amara R., Lagardère F., Désaunay Y., Marchand J., 2000, Metamorphosis and estuarine colonisation in the common sole, Solea solea (L.): implications for recruitment regulation. Oceanol. Acta 23, 469-484.

Anonymous, 2003, Report of the Working Group on the Assessment of Southern Shelf Demersal Stocks. ICES CM 2003/ACFM 03.

Barillé-Boyer A.L., Gruet Y., Barillé L., Harin N., 2004, Temporal changes in community structure of tide pools following the "Erika" oil spill. Aquat. Living Resour. 17, 323. 
Baumard P., Budzinski H., 1997, Internal standard quantification method and gas chromatography-mass spectrometry (GC/MS): a reliable tool for PAH quantification in natural matrices. Analusis 25, 246-252.

Berdugo V. Harris R.P. O'Hara S.C., 1977, The effect of petroleum hydrocarbons on reproduction of an estuarine planktonic copepod in laboratory cultures. Mar. Pollut. Bull. 8, 138-143.

Bretagnolle V., Certain G., Houte S., Métais M., 2004, Distribution maps and minimum abundance estimates for wintering auks in the Bay of Biscay, based on aerial surveys. Aquat. Living Resour. 17, 353.

Budzinski H., Mazéas O., Tronczynsky J., Désaunay Y., Bocquené G., Claireaux G., 2004, Link between exposure of fish (Solea solea) to PAHs and metabolites: application to the "Erika" oil spill. Aquat. Living Resour. 17, 329.

Budzinski H., Papineau A., Baumard P., Garrigues P., 1995, Extraction assistée par chauffage microondes focalisées (MOF) à pression ambiante des composés organiques dans les matrices naturelles : application à l'analyse des composés aromatiques. C. R. Acad. Sci. Paris 321, sér. IIb, 69-76.

Budzinski H., Letellier M., Garrigues P., Le Menach K., 1999, Optimisation of teh microwave-assisted extraction in open cell of PAHs from soils and sediments - Study of moisture effect. J. Chromatogr. A. 837, 187-200.

Burgeot T., Bocquené G., Pingray G., Godefroy D., Legrand J., Dimeet J., Marco F., Vincent F., Henocque Y., Oger Jeanneret H., Galgani F., 1994, Monitoring biological effects of contamination in marine fish along French coasts by measurement of ethoxyresorufin-O-deethylase activity. Ecotoxicol. Environ. Saf. 29, 131-147.

Byrne C.J., Calder J.A., 1977, Effect of the water-soluble fractions of crude, refined and waste oils on the embryonic and larval stages of the quahog clam Mercenaria sp. Mar. Biol. 40, 225-231

Cann-Moisan C., Caroff J., Sebert P., Barthelemy L., 1989, Determination of nucleotide concentrations with high performance liquid chromatography (HPLC): application to fish. Aquaculture 76, 135-143.

Capuzzo J.M., 1980, Biological effect of petroleum hydrocarbons on marine organisms: integration of experimental results and predictions of impacts. Mar. Environ. Res. 17, 272-276.

Claireaux G., Lagardère J.-P., 1999, Influence of temperature, oxygen and salinity on the metabolism of European sea bass. J. Sea Res. 42, 157-168.

Claireaux, G., Webber, D.M., Lagardère J.-P., Kerr, S.R., 2000, Influence of water temperature and oxygenation on the aerobic metabolic scope of Atlantic cod (Gadus morhua). J. Sea Res. 44, 257-265.

Chantereau S., Chiffoleau J.-F., Dufour A., Jeanneret H., 2002, Utilisation des données du RNO dans le cadre du naufrage de l'Erika. In: Travaux du RNO 2002. Surveillance du milieu marin. Ifremer \& Ministère de l'Écologie et du Développement Durable, pp. 25-43.

Connolly J.P., 1991, Application of a food chain model to polychlorinated biphenyl contamination of the lobster and winter flounder food chains in New Bedford harbor. Environ. Sci. Technol. 25, 760-770.

Cravedi J.P., 2001, Métabolisme et bioaccumulation des xénobiotiques chez le poisson. C.R. Acad. Agric. Fr. 87, 199-208.

Daan N., Richardson K., Pope J.G., 1996, Changes in the North Sea ecosystem and their causes: Aarhus 1975 revisited. ICES J. Mar. Sci. 53, 87-883.

Dale V.H., Beyeler S.C., 2001, Challenges in development and use of ecological indicators. Ecol. Indic. 1, 3-10.
Désaunay Y., Pérodou J.B., Beillois P., 1981, Etude des nurseries de poissons du littoral de la Loire Atlantique. Science et Pêche, Bull. Inst. Scient. Techn. Pêches Marit. 319, 1-23.

Désaunay Y., Guérault D., 2002, Manuel des protocoles de campagne halieutique, campagnes Nourriceries Gascogne. IFREMER, Système d'Informations halieutiques, DRV/RH/DT/2002005, 31 .

Dorel, D., Koutsikopoulos C., Désaunay Y., Marchand J., 1991, Seasonal distribution of young sole Solea solea (L.) in the nursery ground of the Bay of Vilaine (northern Bay of Biscay). Neth. J. Sea Res. 27, 297-306.

Fletcher G.L., Kiceniuk J.W., Williams U.P., 1981, Effects of oiled sediments on mortality, feeding and growth of winter flounders Pseudopleuronectes americanus. Mar. Ecol. Prog. Ser. 4, 91-96.

Frid C., Rogers S., Nicholson M., Ellis J., Freeman S., 2000, Using biological characteristics to develop new indices of ecosystem health. Mini-symposium on Defining the role of ICES in supporting biodiversity conservation. ICES CM 2000/Mini: 02, 23 p.

Galgani F., Payne J.F., 1991, Biological effects of contaminants: microplate method for measurement of EROD activity in fish. ICES Techniques in Marine Environmental Sciences 13, 12.

Galois R., Lagardère F., Richard P., 1990, Changes in biochemical composition and otolith microstructure of larval common solea, Solea solea (L.). La Mer 28, 273-285.

Gamperl A.K., Farrell A.P., 2004, Cardiac plasticity in fishes: environmental influences and intraspecific differences. J. Exp. Biol. 207, 2539-2550.

Gamperl A.K., Vijayan M.M., Boutilier R.G., 1994, Experimental control of stress hormone levels in fishes: techniques and application. Rev. Fish Biol. Fish. 4, 215-255.

Goksoyr A., Beyer J., Husoy A.M., Larsen H.E., Westrheim K., Wilhelmsen S., Klungsoyr J., 1994, Accumulation and effects of aromatic and chlorinated hydrocarbons in juvenile Atlantic cod (Gadus morhua) cages in a polluted fjord (Sorfjorden, Norway). Aquat. Toxicol. 29, 21-35.

Hilborn R., 1996, Detecting population impacts from oil spills: a comparison of methodologies. Am. Fish. Soc. Symp.18, 639-644.

Hontela A., Dumont P., Duclos D., Fortin R., 1995, Endocrine and metabolic dysfunction in yellow perch, Perca flavescens, exposed to organic contaminants and heavy metals in the St Lawrence river. Environ. Toxicol. Chem. 14, 725-731.

Hose J.E., McGurk M.D., Marty G.D., Hinton D.E., Brown E.D., Baker T.T., 1996, Sublethal effects of the "Exxon Valdez" oil spill on herring embryos and larvae: morphological, cytogenetic and histopathological assessements, 1989-1991. Can. J. Fish. Aquat. Sci. 53, 2355-2365.

Karakiri M., Berghahn R., Von Westernhagen H., 1989, Growth differences in 0-group plaice Pleuronectes platessa as revealed by otolith microstructure analysis. Mar. Ecol. Prog. Ser. 55, 15-22.

Kiceniuk J.W., Khan R.A., 1987, Effect of petroleum hydrocarbons on Atlantic cod, Gadus morhua, following chronic exposure. Can. J. Zool. 65, 490-494.

Kirby M.F., Neall P., Taylor T., 1999, EROD activity measured in flatfish from the area of the Sea Empress oil spill. Chemosphere 38, 2929-2949.

Kocan R.M., Marty G.D., Okihiro M.S., Brown E.D., Baker T.T., 1996, Reproductive success and histopathology of individual Prince William Sound Pacific herring 3 years after the "Exxon Valdez" oil spill. Can. J. Fish. Aquat. Sci. 53, 2388-2393.

Köhler A., Hölzel F., 1980, Investigation on health conditions of flounder and smelt in the Elbe estuary. Helgol. Meers. 33, 401-414. 
Koutsikopoulos C., Désaunay Y., Dorel D., Marchand J., 1989, The role of coastal areas in the life history of sole (Solea solea L.) in the Bay of Biscay. In: Ros J.D. (Ed.), Topics in Marine Biology. Scient. Mar. 53, 567-575.

Koutsikopoulos C., Lacroix N., 1992, Distribution and abundance of sole (Solea solea L.) eggs and larvae in the Bay of Biscay between 1986 and 1989. Neth. J. Sea Res. 29, 81-91.

Koutsikopoulos C., Dorel D., Désaunay Y., Le Cann B., Forest A., 1995, Interactions entre processus physiques et comportement individuel : conséquences sur l'organisation et le fonctionnement du stock de sole (Solea solea L.) du golfe de Gascogne. ORSTOM (Ed.) Colloques et Séminaires, $1^{\text {er }}$ Forum Halieumétrique, pp. 49-74.

Lancaster J.E., Pawson M.G., Pickett G.D., Jennings S., 1998, The impact of the Sea Empress oil spill on seabass recruitment. Mar. Pollut. Bull. 36, 677-688.

Léauté J.P., Caill-Milly N., 2003, Les petites pêches côtières et estuariennes françaises du sud du golfe de Gascogne. Extrait du rapport final du contrat PECOSUDE EC/DG Fish (DG XIV) No. 99/024, Ifremer, DRV/RH/DT/03-01.

Lee W.Y., Winters K., Nicol J.A.C., 1978, The biological effects of the water-soluble fractions of a No. 2 fuel oil on the planktonic shrimp, Lucifer faxoni. Environ. Pollut. 153, 167-183.

Lefrançois, C., Claireaux, G., 2003, Influence of ambient oxygenation and temperature on metabolic scope and scope for heart rate in the common sole (Solea solea). Mar. Ecol. Prog. Ser. 259, 273-284.

Le Pape O., Désaunay Y., Guérault D., 2003a, Relationship between fluvial discharge and sole (Solea solea L.) recruitment in the Bay of Biscay (France). ICES Mar. Sci. Symp. 219, 241-248.

Le Pape O., Chauvet F., Désaunay Y., Guérault D., 2003b, Relationship between interannual variations of the river plume and the extent of nursery grounds for the common sole (Solea solea L.) in Vilaine Bay. Effects on recruitment variability. J. Sea Res. 50, 177-185.

Le Pape O., Chauvet F., Mahévas S., Lazure P., Guérault D., Désaunay Y., 2003c, Quantitative description of habitat suitability for the juveniles common sole (Solea solea L.) in the Bay of Biscay (France) and the contribution of different habitats to the adult population. J. Sea Res. 50, 139-149.

Le Pape O., Holley J.-F., Guérault D., Désaunay Y., 2003d, Quality of coastal and estuarine essential fish habitats: Estimations based on the size of juvenile common sole (Solea solea L.). Estuar. Coast. Shelf Sci. 58, 793-803.

Linden O., 1978, Biological effects of oil on early development of the Baltic herring Clupea harengus membras. Mar. Biol. 45, 273-283.

Mallatt J., 1985. Fish structural changes induced by toxicants and other irritants: a statistical review. Can. J. Fish. Aquat. Sci. 42, 630-648.

Martoja, R., Martoja-Pierson, M., 1967, Initiation aux techniques de l'histologie animale. Masson Paris, France.

Marty G.D., Short J.W., Dambach D.M., Willits N.H., Heintz R.A., Rice S.D., Stegeman J.J., Hinton D.E., 1996, Ascites, premature emergence, increased gonadal cell apoptosis and cytochrome $\mathrm{P} 4501 \mathrm{~A}$ induction in pink salmon larvae continuously exposed to oil-contaminated gravel during development. Can. J. Zool. 75, 989-1007.

Mazéas L., Budzinski H., 2001, Improved accuracy of GC-MS quantification of aliphatic and aromatic hydrocarbons in marine sediments and petroleums. Validation on reference matrices and application to the Erika oil spill. Intern. J. Environ. Anal. Chem. 82, 157-173.
Mercier, C., Axelsson, M., Imbert, N. Claireaux, G., Lefrançois, C., Altimiras, J., Farrell, A.P., 2002, In vitro cardiac performance in triploid brown trout (Salmo trutta) at two acclimation temperatures. J. Fish Biol. 60, 117-137.

Moles A., Rice S., Norcross B.L., 1994, Non-avoidance of hydrocarbon laden sediments by juvenile flatfishes. Neth. J. Sea Res. 32, 361-367.

Moles A., Norcross B.L., 1998, Effects of oil-laden sediments on growth and health of juvenile flatfishes. Can. J. Fish. Aquat. Sci. 55, 605-610.

Monod G., Saucier D., Perdu-Durand E., Diallo M., Cravedi J.P., Astic L., 1994, Biotransformation enzyme activities in the olfactory organ of rainbow trout (Oncorhynchus mykiss). Immunocytochemical localization of cytochrome P4501 A1 and its induction by B-naphthoflavone. Fish Physiol. Biochem. 13, 433-444.

Moore M.J., Stegeman J.J., 1994, Hepatic neoplasm in winter flounder Pleuronectes americanus from Boston harbor, Massachusett, USA. Dis. Aquat. Org. 20, 33-48.

Peterson C.H., 2001, The "Exxon Valdez" oil spill in Alaska: Acute, indirect and chronic effects on the ecosystem. Adv. Mar. Biol. 39, $1-103$.

Peterson C.H., Rice S.D., Short J.W., Esler D., Bodkin J.L., Ballachey B.E., Irons D.B., 2003, Long-term ecosystem response to the "Exxon Valdez" oil spill. Science 302, 2082-2086.

Priede I.G., 1977, Natural selection for energetic efficiency and relationship between activity level and mortality. Nature 267, 610-612.

Priede I.G., 1985, Metabolic scope in fish. In: Tyler P., Calow P. (Eds.), Fish energetics: new perspectives. Croom Helm, London, pp. 33-64.

Reid SG., Bernier NJ., Perry SF., 1998, the adrenergic stress response in fish: control of catecholamine storage and release. Comp. Biochem. Physiol. C 120, 1-27

Shiels H.S., Stevens E.D., Farrell A.P., 1998, Effect of temperature, adrenaline and ryanodine on power production in rainbow trout Oncorhynchus mykiss ventricular trabeculae. J. Exp. Biol. 201, 2710-2710.

Sogard S., Able K.W., 1992, Growth variation of newly settled winter flounder (Pseudopleurectes americanus) in New Jersey estuaries as determined by otolith microstructure. Neth. J. Sea Res. 29, 163-172.

Soimasuo R., Jokinen I., Kukkonen J., Petanen T., Ristola T., Oikari A., 1995, Biomarker responses along a pollution gradient: effects of pulp and paper mill effluents on caged whitefish. Aquat. Toxicol. 31, 329-345.

Solangi M.A., Overstreet R.M., 1982, Histopathological changes in two estuarine fishes, Menidia beryllina (Cope) and Trinectes maculatus (Bloch and Schneider) exposed to crude oil and its water-soluble fractions. J. Fish Dis. 5, 13-35.

Stehr C.M., Myers M.S., Johnson L.L., Spencer S., Stein J.E., 2003, Toxicopathic liver lesions in English sole and chemical contaminant exposure in Vancouver Harbour, Canada. Mar. Environ. Res. $57,55.74$.

Suthers I.M., 1998, Bigger? Fatter? Or is faster growth better? Considerations on condition in larval and juvenile coral-reef fish. Aust. J. Ecol. 23, 265-273.

Tronczynski J., Munschy C., Moisan K., Guiot N., Truquet I., Olivier N., Men S., Furaut A., 2004, Contamination of the Bay of Biscay by polycyclic aromatic hydrocarbons (PAHs) following the $\mathrm{T} / \mathrm{V}$ "Erika" oil spill. Aquat. Living Resour. 17, 243. 
Truscott B., Idler D.R., Fletcher G.L., 1992, Alteration of reproductive steroids of male winter flounder (Pleuronectes americanus) chronically exposed to low levels of crude oil in sediments. Can. J. Fish. Aquat. Sci. 49, 2190-2195.

Van Den Thillart G., Dalla Via J., Vitali G., Cortesi P., 1994, Influence of long-term hypoxia exposure on the energy metabolism of Solea solea. I. Critical O2 levels for aerobic and anaerobic metabolism. Mar. Ecol. Prog. Ser. 104, 109-117.

Vethaak A.D., Jol J.G., Meijboom A., Eggens M.L., 1996, Skin and liver diseases in flounder (Platichthys flesus) after long-term exposure to contaminated sediments in large scale mesocosms. Environ. Health Perspect. 104, 1218-1229.
Vethaak A.D., Wester P.W., 1996, Diseases in flounder Platichthys flesus in Dutch coastal and estuarine waters, with particular reference to environmental stress factors. II. Liver histopathology. Dis. Aquat. Org. 26, 99-116.

Vettier A., Sébert P., 2004, Pressure resistance of aerobic metabolism in eels from different water environments. Mitochondrion 3, 347-354.

Whitfield A.K., Elliott M., 2002, Fishes as indicators of environmental and ecological changes within estuaries: A review progress and some suggestions for the future. J. Fish Biol. 61 (suppl. A), 229-250. 